\title{
PRZEMIANY WYBRANYCH FORM RZEŹBY TERENU WOJEWÓDZTWA LÓDZKIEGO W OSTATNIM STULECIU
}

\author{
Transformation of selected relief landforms of the Lódź Voivodeship in the last century
}

\author{
JULIUSZ TWARDY*(10
}

\begin{abstract}
Zarys treści. W pracy zajęto się zagadnieniem zmian ukształtowania terenu województwa łódzkiego w okresie minionych 100 lat. Wobec szczupłości materiałów zaprezentowano jedynie szereg przykładów zmian eolicznych form rzeźby oraz wybranych form występujących na stokach - parowów i innych młodych rozcięć erozyjnych. Przekształcanie rzeźby eolicznej w ostatnim 100-leciu wiązało się zarówno z powstawaniem małych, inicjalnych pagórków eolicznych, jak i przeobrażaniem przez wiatr starszych wydm późnoglacjalnych. Zmiany parowów polegały na szybkiej transformacji kształtów ich zboczy pod wpływem uprawy ziemi i objęły od 2,18 do 51,4\% stoków parowów. Podobnie jak w przypadku wydm następowała zarówno transformacja rzeźby wcześniej powstałych parowów neoholoceńskich, jak i tworzyły się na stokach młode i niewielkie, lecz już trwałe formy erozyjne. Analizę zmian rzeźby form eolicznych i form występujących na stokach poprzedzono rozpatrzeniem podatności obszaru województwa łódzkiego na działanie procesów eolicznych i stokowych.
\end{abstract}

Słowa kluczowe: procesy eoliczne, procesy stokowe, województwo łódzkie, Polska Środkowa

\begin{abstract}
The paper presents changes in the relief of the Łódź Voivodeship over the past 100 years. In view of a shortage of data, only a few cases of changes to aeolian landforms and to selected forms appearing on the slopes of gullies and other young erosional cuts were described. The transformation of aeolian relief in the last 100 years was associated with the formation of small, initial aeolian hillocks and with the transformation by wind of older late-glacial dunes. The changes to gullies involved rapid transformation of their slope profiles under the influence of soil cultivation and comprised from 2.18 to $51.4 \%$ of the gullies' slopes. As in the case of the dunes, the transformation of the relief both of former Neoholocene gullies, and of young, small, but permanent erosional forms originated on the slopes took place. Relief analysis of aeolian landforms and features occurring on the slopes was preceded by consideration of the vulnerability of the Łódź Voivodeship area to aeolian activity and slope processes.
\end{abstract}

Keywords: aeolian processes, slope processes, Łódź Voivodeship, Middle Poland

\section{Wprowadzenie}

Obszar województwa łódzkiego kształtują trzy główne grupy procesów morfodynamicznych: procesy rzeczne, stokowe i eoliczne. Mają one największe znaczenie dla zmian rzeźby ostatniego stulecia; mniejszą rolę odgrywa narastanie i decesja złóż torfowych. Podkreślić jednak trzeba, że przyjęty na potrzeby jubileuszu $100-$ lecia województwa łódzkiego interwał jest bardzo krótki w odniesieniu do tzw. geologicznej skali czasu (Goździk 1986). Utrudnia to określenie zmian rzeźby terenu, jakie nastąpiły pod wpływem czynników naturalnych. Dodatkowo nakłada się na powyższą trudność fakt, że natężenie procesów geomorfologicznych, wywołujących zmiany rzeźby nizin środkowopolskich i przedpola wyżyn, jest niskie lub bardzo niskie (rys. 1). Zaledwie około $20 \%$ powierzchni województwa można zaliczyć do obszarów z przewagą procesów degradacji, chodzi tu przede wszystkim o erozję i denudację oraz korazję i deflację o słabym natężeniu. Większość powierzchni województwa łódzkiego to obszar równowagi degradacji i agradacji, na którym działają wyżej wymienione procesy naturalne o bardzo słabym natężeniu, a efekty erozji i akumulacji w pewnym sensie znoszą się wzajemnie i zacierają niewielkie zmiany rzeźby.

* Uniwersytet Łódzki, Wydział Nauk Geograficznych, Katedra Geomorfologii i Paleogeografii, ul. Narutowicza 88, 90-139 Łódź; e-mail: juliusz.twardy@geo.uni.lodz.pl; ORCID: https://orcid.org/0000-0002-6090-0313 


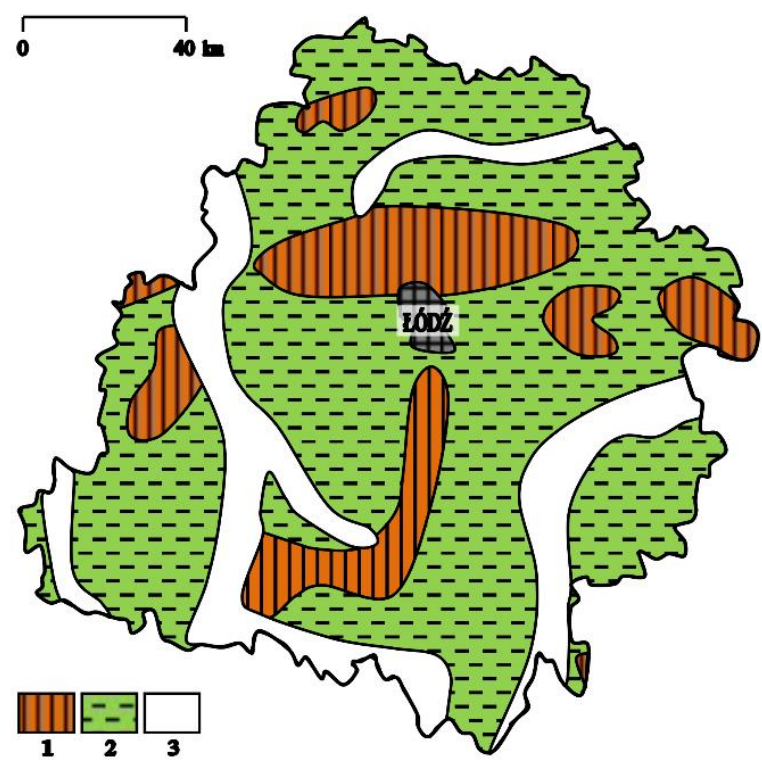

Rys. 1. Typy obszarów morfodynamicznych województwa łódzkiego

(za: Bogacki, Starkel 1999)

1 - obszary degradacji o słabym natężeniu procesów (ostańce moren, kemów i ozów), 2 - obszary o równowadze degradacji i agradacji o bardzo słabym natężeniu procesów (równiny denudacyjne staroglacjalne, równiny sandrowe $\mathrm{z}$ wydmami, terasy dolinne - nadzalewowe), 3 - obszary agradacji (o przewadze agradacji rzecznej)

Types of morphogenetic zones of the Łódź Voivodeship (after: Bogacki, Starkel 1999)

1 - zones of degradation of weak process intensity (residuals of moraines, kames and eskers), 2 - zones of balanced degradation and aggradation with very low process intensity (denudational plains, outwash plains with dunes, river terraces), 3 - zones of aggradation (predominantly of river aggradation)
W województwie łódzkim funkcjonuje jeden geomorfologiczny ośrodek naukowy, który znajduje się w Uniwersytecie Łódzkim. Od chwili jego powstania, zainicjowanego przez prof. Jana Dylika, dominuje w nim podejście paleogeograficzne do zagadnień rozwoju rzeźby terenu, opierające się na zdecydowanie dłuższych odcinkach czasu. Prawie zupełnie nie prowadzono tu badań z zakresu geomorfologii dynamicznej, nie obserwowano natężenia niektórych ważnych procesów geodynamicznych (np. procesów fluwialnych). Obserwacje przebiegu procesów stokowych były krótkotrwałe i nieusystematyzowane, a procesy eoliczne obserwowano jedynie incydentalnie. Przytoczone fakty powodują, że kompleksowe i poszerzone omówienie efektów współczesnej morfogenezy na obszarze województwa łódzkiego z przyczyny braku szerszych materiałów naukowych nie jest możliwe. W takiej sytuacji pozostaje skupić się na przedstawieniu zmian rzeźby wybranych, najbardziej wyrazistych form ukształtowania terenu, kształtowanych przez procesy stokowe i eoliczne.

\section{Cel, zakres i metody badań}

Celem pracy jest scharakteryzowanie kierunków i skali przemian rzeźby terenu województwa łódzkiego, które nastąpiły $\mathrm{w}$ ostatnim stuleciu. $\mathrm{Z}$ uwagi na szczupłość materiałów do bliższej charakterystyki wykorzystano po kilka przykładów form eolicznych (rys. 2, sygnatura 1), takich jak rozwiewane wydmy i kopczyki eoliczne oraz form sto- kowych (rys. 2, sygnatura 2), to znaczy parowów i młodych rozcięć erozyjnych.

Zakres przestrzenny niniejszej pracy wyznaczają współczesne granice województwa łódzkiego. Zakres czasowy związany jest ze 100-letnim istnieniem odrodzonej Rzeczypospolitej Polskiej i funkcjonowaniem województwa łódzkiego. Zakres problemowy z wyżej podanych przyczyn koncentruje się wokół ewolucji wybranych form rzeźby, kształtowanych przez 2 spośród 3 najważniejszych procesów morfogenetycznych, które transformowały rzeźbę terenu województwa łódzkiego w ostatnim stuleciu. Z pracy wyłączono zagadnienie form powstających wskutek różnorodnych prac inżynieryjnych, wydobywania kopalin, hydrotechnicznej zabudowy cieków i innych przedsięwzięć technicznych, albowiem ich badanie jest przedmiotem geotechniki czy inżynierii lądowej, a nie geomorfologii i geografii.

Podłódzkie parowy badano (Twardy 1995, 2008; Forysiak, Twardy 2012) standardowymi metodami geomorfologicznymi i z zakresu geologii czwartorzędu, nawiązującymi do zasad tzw. metody strukturalnej (Dylikowa 1952). W niniejszej pracy odwołano się do treści własnych, oryginalnych zdjęć topograficznych parowów, wykonanych metodami tachymetrycznymi (z wykorzystaniem teodolitu) lub tzw. zdjęć teletopowych, opracowywanych za pomocą bazowego tachymetru koincydencyjnego „Teletop”. Zdjęcia topograficzne w dużej skali (od 1:500 do 1:1000) parowów w AnielinieLipce i w Brzezinach wykonano na początku lat 90. ubiegłego wieku. Parów w Dąbrówce Dużej karto- 


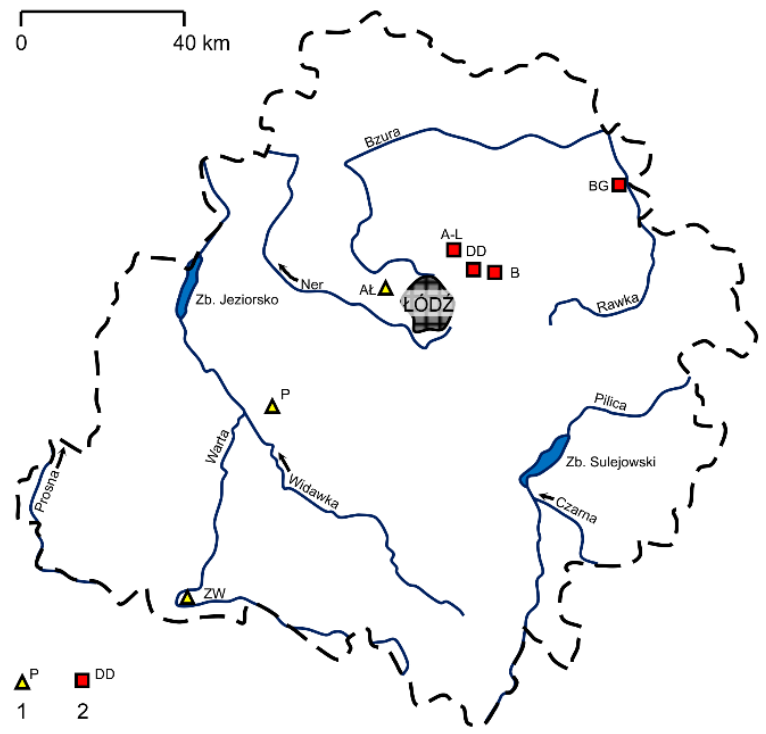

Rys. 2. Województwo łódzkie - mapa dokumentacyjna

1 - wymienione w tekście stanowiska ze zmianami rzeźby form eolicznych, 2 - wymienione w tekście stanowiska ze zmianami rzeźby form stokowych; objaśnienia skrótów: ZW - Załęcze Wielkie, P - Poręby, AŁ - Aleksandrów Łódzki, A-L - Anielin-Lipka, DD - Dąbrówka Duża, B - Brzeziny, BG - Budy Grabskie

Łódź Voivodeship - documentation map

1 - sites cited in the text with changes in the relief of aeolian forms, 2 - sites cited in the text with changes in the relief of slope forms; explanation of abbreviations: ZW - Załęcze Wielkie, P - Poręby, AŁ - Aleksandrów Łódzki, A-L - Anielin-Lipka, DD - Dąbrówka Duża, B - Brzeziny, BG - Budy Grabskie wano dwukrotnie - w latach 60. XX wieku i w roku 1984 (Wieczorkowska 1986, 1997), natomiast młode rozcięcie erozyjne (mały parów) w Budach Grabskich skartowano w roku 2010 (Forysiak, Twardy 2012). Podczas kartowania wymienionych form określano kształty stoków parowów, co pozwoliło je zakwalifikować jako naturalne (stoki o kształtach prostych, wyraźne górne i dolne załamanie stoku) i przekształcone przez uprawę ziemi (stoki o kształtach wypukło-wklęsłych i wypukłych).

Osady kopczyka eolicznego w Załęczu Wielkim poddano badaniom teksturalnym i strukturalnym (Rzepecki i in. 2015). Wynik datowania ${ }^{14} \mathrm{C}$ drewna z podłoża wspomnianego kopczyka eolicznego pochodzi z Laboratorium Datowań Bezwzględnych w Skale (oznaczenie MKL), tam też datowano drewno przykryte osadami stożka akumulacyjnego młodego rozcięcia erozyjnego w Budach Grabskich. Pozostałe, przytoczone w tekście, wyniki datowań ${ }^{14} \mathrm{C}$ gleb kopalnych oraz drewna podścielającego osady $\mathrm{z}$ okresu intensywnego rozwoju podłódzkich wąwozów pochodzą z Pracowni ${ }^{14} \mathrm{C}$ Muzeum Archeologicznego i Etnograficznego w Łodzi (oznaczenie LOD).

\section{Uwarunkowania przemian form eo- licznych i stokowych}

Wobec skromnych materiałów możliwości przemian rzeźby eolicznej w okresie ostatnich 100 lat należy oceniać biorąc pod uwagę wiedzę o uwarunkowaniach współczesnych procesów eolicznych w centralnej Polsce. Procesy eoliczne w województwie łódzkim zachodzą współcześnie i zachodziły w ostatnim stuleciu w środowisku silnie przekształconym przez człowieka. Ich natężenie wynikało i wynika ze splatających się ze sobą czynników naturalnych i antropogenicznych, takich jak: warunki anemologiczne, pokrycie terenu, wrażliwość gleb uprawnych na działalność wiatru, rzeźba terenu, stosunki wodne i inne. Za Wojtanowiczem (1999, 2009) można przyjąć, że w centralnej Polsce współczesne warunki anemologiczne są wystarczające do tego, aby wiatr mógł przejawiać działalność niszczącą, transportową i akumulacyjną. Zasada aktualizmu pozwala zakładać, że generalnie zbliżone warunki występowały w ostatnim 100-leciu.

$\mathrm{Z}$ jednej strony niska lesistość województwa łódzkiego oraz występujący $\mathrm{w}$ nim stosunkowo duży odsetek gruntów ornych sprzyjają procesom eolicznym, szczególnie deflacji materiału z powierzchni niechronionych lub słabo chronionych przez roślinność uprawną (Józefaciuk, Józefaciuk, 1995). $Z$ drugiej strony należy stwierdzić, że obszary najbardziej wrażliwe na działalność wiatru licznie występujące w województwie łódzkim obszary pokryte późnovistuliańskimi wydmami i pokrywami eolicznymi (Galon 1958; Dylikowa 1967) - pozostają współcześnie w stanie zalesienia, co stoi na przeszkodzie ich dalszemu rozwojowi. Trzeba jednak pamiętać, że wobec presji na zagospodarowywanie nawet stosunkowo słabych gleb, jaka występowała w okresie II Rzeczypospolitej, niektóre pola eoliczne w województwie łódzkim nie były stabilne (Kossman 1930).

Obszar centralnej Polski charakteryzuje się stosunkowo dużą podatnością gleb na deflację (rys. 3A). Tereny szczególnie wrażliwe na rozwiewanie gleb koncentrują się na Wysoczyźnie Złoczewskiej, w Kotlinie Szczercowskiej i południowej części 
Wysoczyzny Łaskiej. Dominują tu gleby o lekkim składzie ziarnowym, rozwinięte z piasków (najczęściej z piasków eolicznych), należące do działu gleb autogenicznych, rzędu gleb bielicoziemnych i typów gleb bielicowych, rdzawych oraz bielic (Musierowicz 1961a, b; Zawadzki 2002). Wraz ze wzrostem udziału materiału bardziej drobnoziarnistego niż piasek w składzie mechanicznym gleb spada ich podatność na deflację (Józefaciuk, Józefaciuk 1995). W związku z tym ciężkie gleby Równiny Łowicko-Błońskiej i Równiny Kutnowskiej oraz częściowo Kotliny Kolskiej wykazują jedynie słaba i bardzo słabą podatność na procesy rozwiewania.

Z właściwości pedosfery, rzeźby terenu i stosunków wodnych wynika zagrożenie gruntów ornych erozją wietrzną (rys. 3B). Obszary bardzo silnego zagrożenia koncentrują się na północnym skraju Wyżyny Wieluńskiej, w zbliżonym do południkowego pasie przebiegającym przez Kotlinę Szczercowską, Wysoczyznę Łaską oraz - już w mniejszych kompleksach - na obszarach wododziałowych Wzniesień Łódzkich i Wysoczyzny Rawskiej. Największy obszar bardzo silnego zagrożenia pokrywa się z rozległym płatem osadów i form eolicznych zajmujących Kotlinę Szczercowską (Gawlik 1969).

Rys. 3. Uwarunkowania przemian rzeźby eolicznej województwa łódzkiego

A - podatność gleb na deflację (za: Józefaciuk, Józefaciuk 1995): 1 - bardzo silna, 2 - silna, 3 - średnia, 4 - słaba i bardzo słaba, 5 - ważniejsze lasy; B - zagrożenie erozją wietrzną gruntów rolnych (za: Józefaciuk, Józefaciuk 1979): 1 - bardzo silne, 3 - silne, 4 - średnie, 4 - nie wystepuje; $\mathrm{C}$ - intensywność współczesnych autochtonicznych procesów eolicznych (za: Wojtanowicz 1999): procesy eoliczne w warunkach antropopresji, 1 - umiarkowane $\left(200-500 \mathrm{t} \cdot \mathrm{km}^{-2} \cdot \mathrm{rok}^{-1}\right.$, średnio $\left.300 \mathrm{t} \cdot \mathrm{km}^{-2} \cdot \mathrm{rok}^{-1}\right)$, słabe $\left(50-200 \mathrm{t} \cdot \mathrm{km}^{-2} \cdot \mathrm{rok}^{-1}\right), 3$ - proces nie występuje lub występuje sporadycznie, np. na rozwiewanych wydmach, 4 - procesy eoliczne w warunkach naturalnych, 5 intensywna działalność eoliczna w dużych odkrywkach i na zwałach

Conditions for the transformation of aeolian relief in the Łódź Voivodeship

A - vulnerability of soils to deflation (after: Józefaciuk, Józefaciuk 1995): 1 - very strong, 2 - strong, 3 - medium, 4 weak and very weak, 5 - major forests; $\mathrm{B}$ - wind erosion risk of agricultural land (after: Józefaciuk, Józefaciuk 1979): 1 very strong, 2 - strong, 3 - medium, 4 - does not occur; C intensity of contemporary autochthonic aeolian processes (after: Wojtanowicz 1999): aeolian processes under human impact: 1 - medium (200-500 $\mathrm{t} \cdot \mathrm{km}^{-2} \cdot \mathrm{yr}^{-1}, 300 \mathrm{t} \cdot \mathrm{km}^{-2} \cdot \mathrm{yr}^{-1}$ on average), 2 - weak (50-200 $\left.\mathrm{t} \cdot \mathrm{km}^{-2} \cdot \mathrm{yr}^{-1}\right), 3$ - process does not occur or occurs sporadically, e.g. on deflated dunes, 4 - aeolian processes in natural conditions, 5 - intense aeolian activity in large open pits and dumping grounds
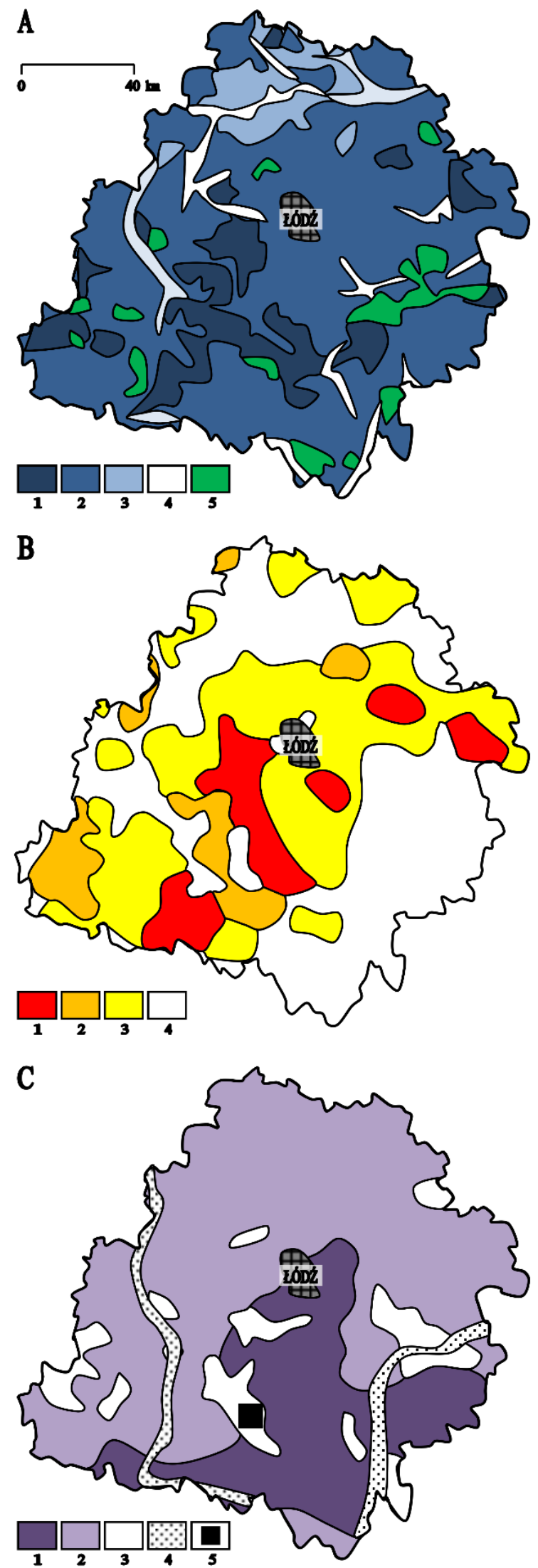
Wyżej omówione mapy korespondują z kartograficznym obrazem współczesnych autochtonicznych procesów eolicznych (rys. 3C). Podkreślić trzeba, że w województwie łódzkim zdaniem Wojtanowicza (1999) zupełnie nie zaznaczają się obszary bardzo silnego natężenia współczesnych autochtonicznych procesów eolicznych (500$1000 \mathrm{t} \cdot \mathrm{km}^{-2} \cdot \mathrm{rok}^{-1}$, średnio $\left.600 \mathrm{t} \cdot \mathrm{km}^{-2} \cdot \mathrm{rok}^{-1}\right)$, które obejmują tereny górskie, pogórskie i przedgórskie oraz wyżyny lessowe. Występuje tu jedynie natężenie umiarkowane $\left(200-500 \mathrm{t} \cdot \mathrm{km}^{-2} \cdot \mathrm{rok}^{-1}\right)$, zaznaczające się w wyżynnych częściach województwa łódzkiego oraz na wododziałowym „półwyspie” przebiegającym przez wschodnie skraje Kotliny Szczercowskiej, a także zachodnie części Wysoczyzny Bełchatowskiej i Wzniesień Łódzkich.

Podsumowując, należy stwierdzić, że procesy eoliczne $\mathrm{w}$ generalnych zarysach mają w województwie łódzkim silnie zróżnicowane warunki rozwoju. Tereny szczególnie narażone koncentrują się w wyżej położonej, centralnej i południowej części województwa, na obszarze garbu wododziałowego i jego wyżynnych części. Najniżej położone północne części województwa z gęstą siecią rzeczną (Maksymiuk 1992), pokryte ciężkimi glebami hydrogenicznymi, semihydrogenicznymi i autogenicznymi ukształtowanymi z glin zwałowych, są praktycznie wolne od procesów rozwiewania gleb i morfotwórczej działalności wiatru. Można przyjąć, że omówiony wyżej przestrzenny rozkład natężenia procesów eolicznych, a także ewolucji rzeźby eolicznej, był charakterystyczny dla minionego stulecia.

Możliwości potencjalnych zmian rzeźby stoków w województwie łódzkim w ostatnich 100 latach można ocenić na podstawie opracowań kartograficznych (rys. 4), ilustrujących zagadnienia erozji wodnej i wąwozowej (Józefaciuk, Józfaciuk 1992, 1995). Natężenie procesów stokowych, głównie spłukiwania, w przypadku Nizin Środkowopolskich jest warunkowane czynnikami środowiskowymi - klimatycznymi (szczególnie sumy, rozkład i charakter opadów atmosferycznych $\mathrm{w}$ roku), pedologicznymi (por. rys. 4A), geomorfologicznymi i geologicznymi oraz hydrograficznymi, a także czynnikami antropogenicznymi (użytkowanie ziemi, zabiegi agrotechniczne, zabiegi przeciwerozyjne).

Obszar województwa łódzkiego cechuje się zasadniczo średnią podatnością gleb na erozję wodną (rys. 4A). Niemniej na jego terenie występują obszary zarówno bardzo silnej podatności, jak i obszary z podatnością słabą i bardzo słabą. Bardzo silnie podatne na erozję wodną są gleby „kompleksu gleb brunatnych, płowych i brunatnych wyługowanych oraz odgórnie oglejonych, wytworzonych z lessów i pyłów innej genezy" (Zawadzki 2002). Przywołane za Zawadzkim (2002) wyróżnienie dotyczy gleb wykształconych z pyłów powstałych podczas vistuliańskiej morfogenezy peryglacjalnej, albowiem na terenie województwa łódzkiego nie występują lessy sensu stricto (Maruszczak 1980), natomiast wspomina się o utworach lessopodobnych (Dylik 1951, 1952). Należy tu podkreślić, że obszary bardzo silnej podatności gleb na erozję wodną cechują się stosunkowo monotonną, równinną rzeźbą terenu. Powoduje to, że są przeważnie objęte potencjalną erozją wodną o jedynie słabym natężeniu. Podatność silna jest związana z katenami rzędu gleb bielicoziemnych, rozwiniętymi z piasków różnej genezy, w tym z piasków wydmowych.

Mapy potencjalnej erozji wodnej (rys. 4B) obrazują zagrożenie terenu procesami wodnej erozji powierzchniowej (Józefaciuk, Józefaciuk 1996). Powierzchnia województwa łódzkiego $\mathrm{w}$ połowie nie jest zagrożona wymienionymi procesami; w nieco wyżej położonej i lepiej urzeźbionej środkowej i południowej części województwa zagrożenie jest słabe, a lokalnie - na niewielką już skalę - średnie. Silne zagrożenie występuje w centralnej części strefy północnej krawędzi Wzniesień Łódzkich oraz w centrum czołowomorenowej strefy Wzgórz Radomszczańskich.

Mapa erozji wąwozowej (rys. 4C) wskazuje, że generalnie rozwój tego rodzaju erozji linijnej nie jest problemem w województwie łódzkim, podobnie jak na całych Nizinach Środkowopolskich (Jozefaciuk, Józefaciuk 1992). Umiarkowane, a lokalnie średnie natężenie erozja wąwozowa osiaga w strefie północnej krawędzi Wzniesień Łódzkich (Twardy 1995, 2005) i w południowej części Wysoczyzny Rawskiej, a także w rejonie przełomu Warty przez Wyżynę Wieluńską (Krzemiński 1965), gdzie w okolicach Toporowa i Przywozu wąwozy (parowy) występują na stromym lewym zboczu dolinnym.

Biorąc pod uwagę cechy środowiska województwa łódzkiego, należy ocenić, że przemiany rzeźby stoków w ostatnim stuleciu występowały głównie w rejonie północnej krawędzi Wzniesień Łódzkich (co ma potwierdzenie w wynikach badań autora - por. Twardy 1995, 2012) i w południowej części Wysoczyzny Rawskiej. Występuje tam średnie, a lokalnie także silne zagrożenie erozją wodną (powierzchniową), jak i zachodzą procesy erozji wąwozowej o umiarkowanym i średnim natężeniu. 


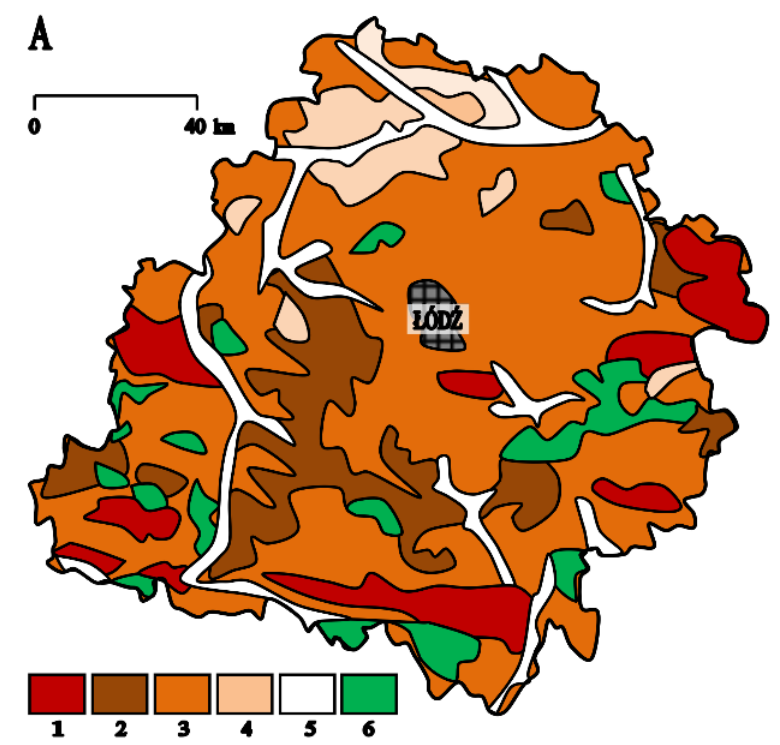

Rys. 4. Uwarunkowania przemian rzeźby stoków województwa łódzkiego

A - podatność gleb na erozję wodną (za: Józefaciuk, Józefaciuk 1995): 1 - bardzo silna, 2 - silna, 3 - średnia, 4 - słaba, 5 - bardzo słaba, 6 - ważniejsze lasy; B - potencjalna erozja wodna (za: Józefaciuk, Józefaciuk 1995): 1 - silna, 2 - średnia, 3 - słaba, 4 - nie występuje; $\mathrm{C}$ - erozja wąwozowa (za: Józefaciuk, Józefaciuk 1995): 1 - średnia (gęstość wąwozów $0,5-1,0 \mathrm{~km} \cdot \mathrm{km}^{-2}$ ), 2 - umiarkowana (gęstość wąwozów $0,1-$ $\left.0,5 \mathrm{~km} \cdot \mathrm{km}^{-2}\right), 3$ - nie występuje

Conditions for the transformation of slopes' relief in the Łódź Voivodeship

A - vulnerability of soil to water erosion (after: Józefaciuk, Józefaciuk 1995): 1 - very strong, 2 - strong, 3 - medium, 4 - weak, 5 - very weak, 6 - major forests; B - potential soil water erosion (after: Józefaciuk, Józefaciuk 1995): 1 strong, 2 - medium, 3 - weak, 4 - does not occur; C - gully erosion (after: Józefaciuk, Józefaciuk 1995): 1 - medium (gully density $0.5-1.0 \mathrm{~km} \cdot \mathrm{km}^{-2}$ ), 2 - moderate (gully density $0.1-0.5 \mathrm{~km} \cdot \mathrm{km}^{-2}$ ), 3 - does not occur

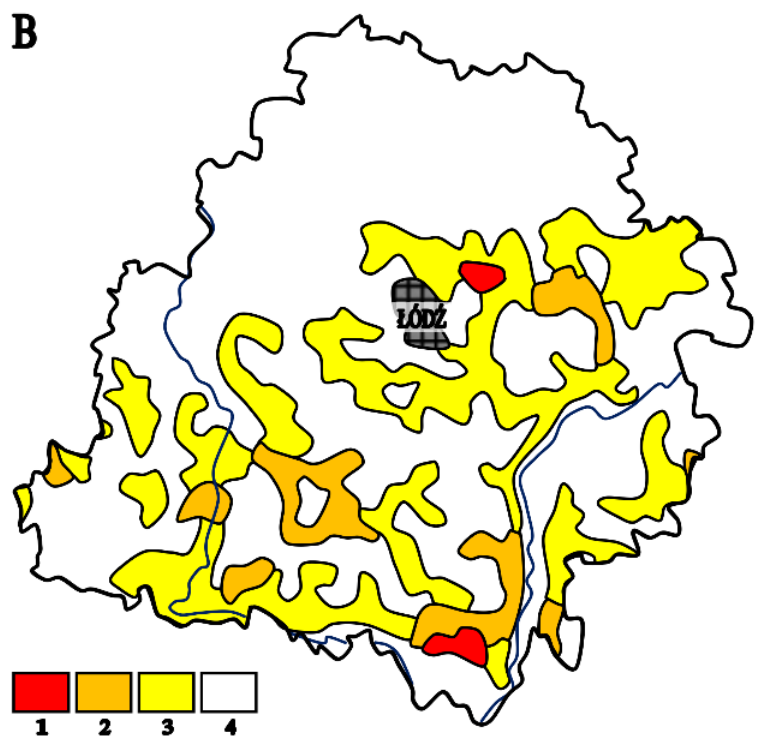

\section{Przemiany wybranych form eolicznych}

Wobec znacznie zróżnicowanych warunków rozwoju procesów eolicznych w województwie łódzkim i ich jedynie słabego względnie umiarkowanego natężenia można wskazać zaledwie pojedyncze przykłady przemian form geomorfologicznych pod wpływem wiatru, które wystąpiły w minionym stuleciu (rys. 2, sygnatura 1).

Na obszarze Wyżyny Wieluńskiej, w załęczańskim przełomie Warty, wewnątrz charakterystycznego tuku („kolana”) wymienionej rzeki opisano (Rzepecki i in. 2015) niewielką formę eoliczną - tzw. kopczyk eoliczny (por. Twardy 2008), położoną na niskiej terasie rzecznej. Forma ta, o zarysie zbliżonym do kolistego i tarczowatym kształcie, przypominała pradziejowy kurhan. Osiągała średnicę blisko $10 \mathrm{~m}$, a jej wysokość wynosiła około $0,8 \mathrm{~m}$. W odróżnieniu od nieinwazyjnych badań podobnych form przedstawionych ostatnio przez Hildebrand-Radke $i$ in. (2018), w Załęczu Wielkim uzyskano zgodę na wykonanie wkopu sondażowego ukazującego wewnętrzną strukturę kopczyka (fot. 1). Materiał budujący kopczyk eoliczny był zupełnie jałowy od strony archeologicznej; stanowily go pozbawione czytelnej struktury piaski drobnoziarniste, dość dobrze wysortowane, wzbogacone $\mathrm{w}$ domieszkę węgla organicznego, który osiągał koncentrację do $1-1,2 \%$. Osady te złożone były na silnie zredukowanym poziomie orno-próchnicznym gleby kopalnej porolnej, najlepiej widocznym w centralnej części kopczyka (prawa część 
kadru, fot. 1). Pośrodku kopczyka, na wspomnianej glebie kopalnej, odkryto subfosylny pień drzewa, które najprawdopodobniej w swoim pobliżu wymuszało akumulację eoliczną drobnoziarnistego, lekko próchnicznego materiału, uruchamianego i transportowanego przez wiatr na okolicznych polach uprawnych. Drewno to wykazało wiek ${ }^{14} \mathrm{C}$ młodszy niż 200 lat BP, wynoszący $10 \pm 50$ lat BP (MKL-2111), co odnosi inicjację akumulacji eolicznej i początek powstawania kopczyka do połowy XX wieku. Przykład z Załęcza Wielkiego wskazuje, że w ostatnim 100-leciu w województwie łódzkim działalność wiatru mogła mieć wymiar morfotwórczy. Podkreślić jednak trzeba, że powstające wówczas formy były co najmniej o rząd wielkości mniejsze od typowych dla regionu łódzkiego późnovistuliańskich wydm parabolicznych i łukowo-parabolicznych, miały nieregularne, nieswoiste dla wydm kształty. Reprezentowały jedynie początkowe - embrionalne - stadium rozwojowe i cechowały się statycznością, nie wykazując śladów migracji, tak charakterystycznej dla w pełni wykształconych wydm śródlądowych. Jest to zgodne $\mathrm{z}$ wieloma obserwacjami powstawania i ewolucji niewielkich, współczesnych form eolicznych (Szczypek, Wach 1991, 1993, 1998; Szczypek 1994a, b; Pełka-Gościniak 2000 i inni), w znacznej mierze podobnych do omówionego kopczyka eolicznego z Załęcza Wielkiego.
Oprócz powstawania nowych, małych form eolicznych minione 100-lecie zapisało się w województwie łódzkim przeobrażeniami późnovistuliańskich wydm i pokryw eolicznych. W latach 70. ubiegłego wieku procesy eoliczne były aktywne na dużej wydmie późnovistuliańskiej w miejscowościach Poręby i Ogrodzisko na Wysoczyźnie Łaskiej (rys. 2, sygnatura 1, fot. 2). Przyczyny braku ustabilizowania wydmy mogły być co najmniej dwie - rabunkowa gospodarka leśna $\mathrm{w}$ drzewostanach sosnowych porastających wcześniej wydmę i być może nadmierny wypas. Ogołocenie wydmy z roślinności powodowało uruchomienie przez wiatr materiału piaszczystego i pylastego, przemiany mikrorzeźby wydmy i pokrycie jej młodymi, drobnymi, podrzędnymi formami eolicznymi, przez Dylikową (1958) określanymi jako „zaspy piaszczyste”. Na zdjęciu lotniczym można rozpoznać ślady współczesnej akumulacji cienkich pokryw eolicznych w otoczeniu wydmy (por. fot. 2). Zdjęcie ukazuje także rozpoczęte dolesienia wydmy, szczególnie dobrze czytelne w najwyższej i najszerszej południowej części formy. Skutkiem planowych dolesień było przerwanie żywych procesów eolicznych i zachowanie do współczesności ustabilizowanej przez leśną monokulturę sosnową wydmy w Porębach i Ogrodzisku.

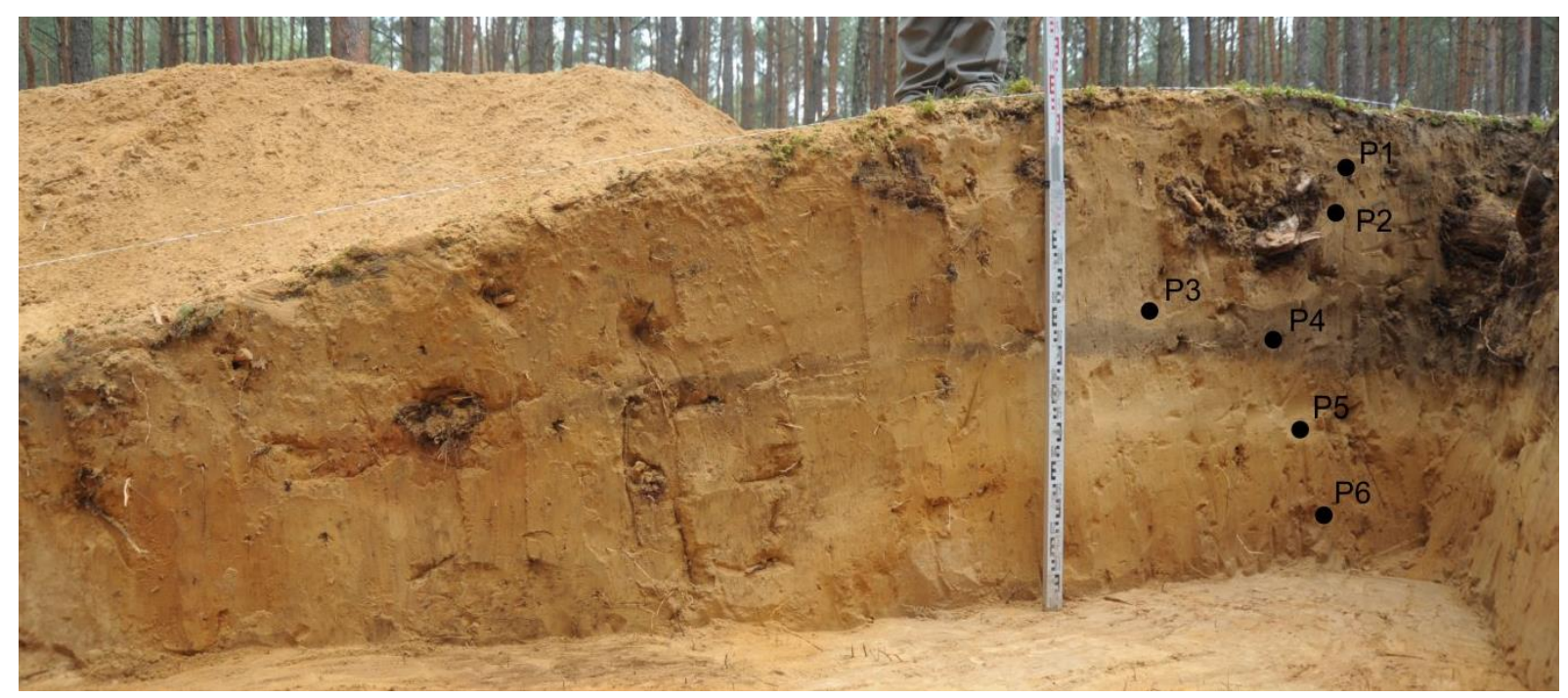

Fot. 1. Struktura kopczyka eolicznego w Załęczu Wielkim (za: Rzepecki i in. 2015)

oznaczono miejsca poboru próbek do badań laboratoryjnych

Structure of a small aeolian hillock in Załęcze Wielkie (after: Rzepecki et al. 2015)

sampling locality marked 


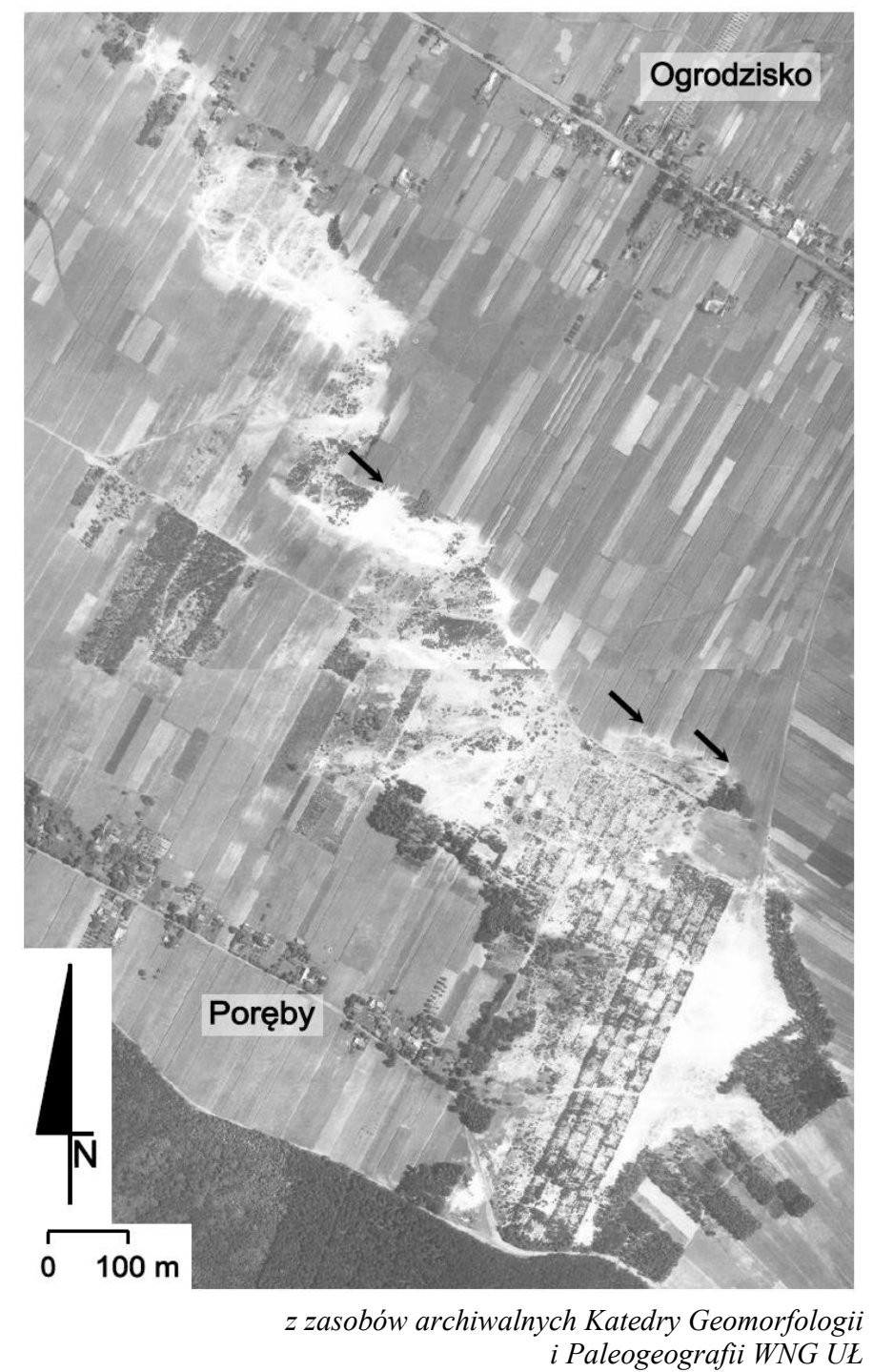

Fot. 2. Wydma w Porębach/Ogrodzisku (Wysoczyzna Łaska) na zdjęciu lotniczym

strzałkami oznaczono akumulację materiału eolicznego na polach uprawnych otaczających wydmę

Dune in Poręby/Ogrodzisko (Łask Plateau) in an aerial photo

arrows denote aeolian accumulation on cultivated fields around the dune

W przypadku większych, bardziej zwartych kompleksów nieustabilizowanych wydm późnovistuliańskich, na przykład wydm kampinoskich (znajdujących się tuż poza zasięgiem województwa łódzkiego), uruchamiane były większe masy materiału eolicznego, co pociągało za sobą znaczniejsze efekty rzeźbotwórcze. W ostatnim 100-leciu został wznowiony proces migracji jednej z wydm kampinoskich, która w okresie 40 lat przesunęła się o $30 \mathrm{~m}$ (Kobendza, Kobendza 1958).

Inny przykład aktywności wydmy późnovistuliańskiej pochodzi z pogranicza Wysoczyzny Łaskiej i Wzniesień Łódzkich, z wydmy położonej na zachód od Aleksandrowa Łódzkiego (rys. 2, sygnatura 1). Podobnie do wydmy w Porębach i Ogrodzisku, w latach 20. i 30. XX wieku pro- cesom rozwiewania podlegała stosunkowo duża wydma późnoglacjalna (Kossman 1930). Wydma ta cechuje się dobrze rozwiniętą częścią czołową, zredukowanym przez rozwiewanie ramieniem północnym i względnie dobrze wykształconym ramieniem południowym. Bezleśna, stosunkowo rozległa i płaska powierzchnia szczytowa czołowej części wydmy w wymienionym okresie stanowiła arenę morfotwórczej działalności wiatru. Podobnie jak to miało miejsce w wydmach kampinoskich, został tu wznowiony proces migracji wydmy. Rozpoczęło się zasypywanie materiałem eolicznym najpierw najbliższych drzew (fot. 3), co można obserwować współcześnie w nadmorskich wydmach Słowińskiego Parku Narodowego, tzw. Madwinach lub Wydmie Czołpiń- 
skiej. W wydmie aleksandrowskiej akumulacja eoliczna przesunęła się następnie na pobliskie pola uprawne, co przynosiło straty gospodarcze. Morfologiczny rozwój wydmy w Aleksandrowie
Łódzkim został przerwany w okresie II wojny światowej przez jej zalesienie. W takim stanie wydma przetrwała do chwili obecnej.

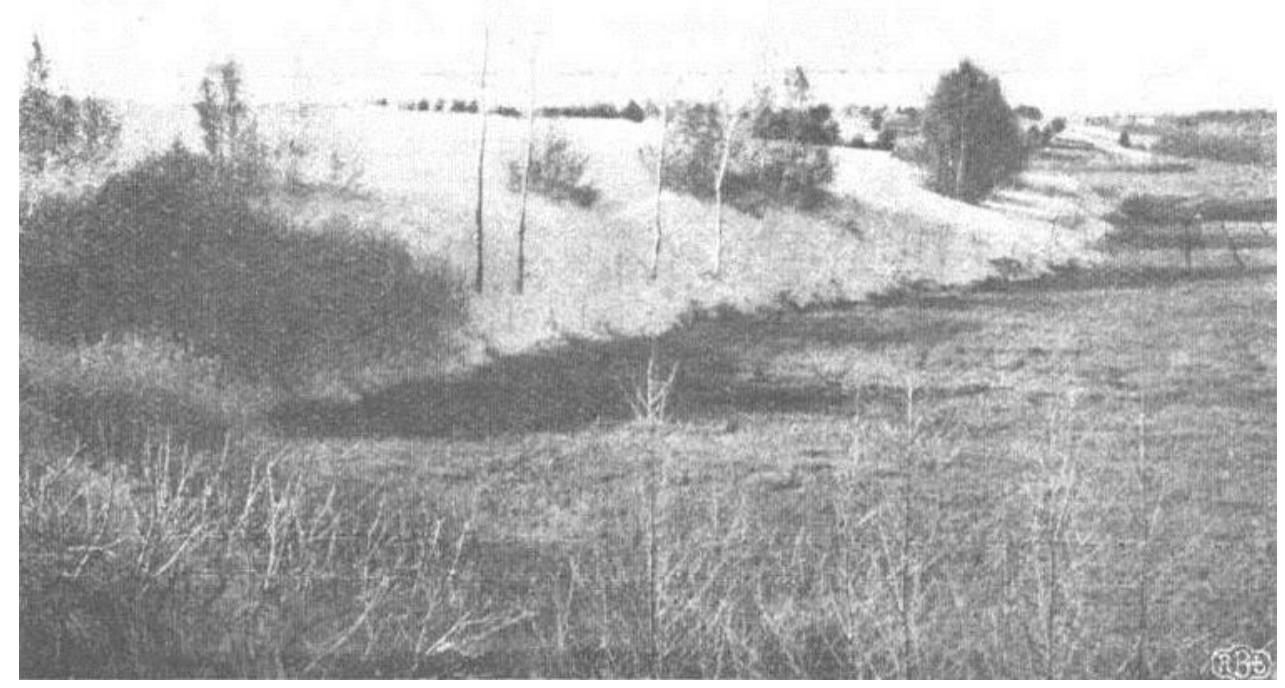

Fot. 3. Wydma w Aleksandrowie Łódzkim zasypująca drzewa (za: Kossman 1930)

Sand dune covering trees in Aleksandrów Łódzki (after: Kossman 1930)

Wyżej przytoczone przykłady transformacji rzeźby eolicznej województwa łódzkiego, pochodzące $\mathrm{z}$ minionego stulecia, zawierają się $\mathrm{w}$ antropogenicznej fazie wydmotwórczej (Twardy 2016). Jest ona odpowiednikiem wyróżnianej dawniej przez Dylikową (1958) tzw. fazy niszczenia i w Polsce Środkowej jest chronologicznie odnoszona do mezo- i neoholocenu. Jednym z ważniejszych wyróżników antropogenicznej fazy wydmotwórczej jest różnorodna transformacja form uprzednich (pokryw eolicznych i wydm późnovistuliańskich), jak i powstawanie nowych, małych form eolicznych, takich jak nieregularne pagórki wydmowe i kopczyki eoliczne.

\section{Przemiany wybranych form stokowych}

Jak wyżej powiedziano, efekty ewolucji form stokowych są najłatwiejsze do zauważenia w przypadku form o wyrazistej, żywej rzeźbie - na przykład parowów i innych młodych rozcięć erozyjnych. Procesy erozji wąwozowej, w swoim ostatnim stadium prowadzące do ukształtowania się parowów, wywołują straty w rolnictwie (Ziemnicki, Józefaciuk 1965). Ich konsekwencją jest degradacja gleb, ale również zmniejszanie się areału gruntów zdatnych do uprawy. Wobec niezbyt dużych roz- miarów podłódzkich parowów rolnicy podejmowali próby zrekultywowania płytszych części parowów i odtworzenia - choćby częściowego - układu pól uprawnych i tym samym włączenia zrekultywowanych gruntów do uprawy. W tym celu prowadzono orkę niezbyt stromych i niewysokich zboczy parowów, a pola uprawne sprowadzano po stokach na dno parowu. Początkowo korzystano z zaprzęgów, ale zwykle po kilku sezonach uprawy było możliwe prowadzenia w strefie parowu zmechanizowanych prac polowych (informacje ustne). Procesy te prowadziły do szybkiego spłaszczania zboczy parowu i nadawania im łagodnego wypukło-wklęsłego lub wypukłego kształtu. Profil poprzeczny parowu poddanego omówionym zabiegom rekultywacyjnym nabierał nieckowatego charakteru i stopniowo coraz bardziej odbiegał od wciosowego (lub skrzynkowego), naturalnego dla parowów profilu poprzecznego, a zaczynał przypominać łagodne profile peryglacjalnych niecek i dolin denudacyjnych. Tego rodzaju zmiany rzeźby parowów zachodziły głównie pod wpływem procesów denudacji agrotechnicznej (Zaslavskij 1978; Sinkiewicz 1989), przez gleboznawców nazywanych erozją uprawową (Ziemnicki, Józefaciuk 1965). Były one połączone $\mathrm{z}$ oddziaływaniem naturalnych procesów stokowych, głównie spłukiwania, występującego na polach uprawnych zbiegających na dno parowów. Prowadzone wieloma metodami badania denudacji agro- 
technicznej wskazują na dużą rolę tych procesów we współczesnej ewolucji rzeźby stoków uprawnych (Brown i in. 1981; Sinkiewicz 1989, 1991, 1995, 1998; Govers i in. 1994; Zgłobicki 2002; Twardy 2008; Szpikowski 2010; Janicki 2016 i inni). Przyspieszenie denudacji agrotechnicznej wiąże się przede wszystkim ze zmechanizowaną uprawą ziemi i pracą pługów wieloskibowych. W Polsce Środkowej początki mechanizacji prac polowych następowały w okresie II Rzeczypospolitej, a na szerszą skalę w II połowie XX w., co dość dokładnie odpowiada 100-letniej cezurze czasowej przyjętej na potrzeby niniejszej pracy.

Do prześledzenia skali zmian rzeźby parowów występujących w województwie łódzkim wybrano kilka przykładowych form: trzy parowy ze strefy północnej krawędzi Wzniesień Łódzkich (parów w Anielinie-Lipce, Dąbrówce Dużej i Brzezinach por. rys. 2, sygnatura 2) oraz znajdujące się na Równinie Łowicko-Błońskiej młode rozcięcie stoku doliny Rawki w Budach Grabskich.

Parów w Anielinie-Lipce (rys. 5) jest najprawdopodobniej największym tego rodzaju systemem w województwie łódzkim. Cechuje się dużą sumaryczną długością ramion i bocznych odnóg (około $4000 \mathrm{~m})$, rekordowo wysoką gęstością rozcięć $\left(4,62 \mathrm{~km} \cdot \mathrm{km}^{-2}\right)$ oraz dużą objętością całej formy wklęsłej $\left(100530 \mathrm{~m}^{3}\right)$. Podkreślić jednak trzeba, że jest to forma kilkukrotnie mniejsza od podobnych genetycznie wąwozów lessowych, zarówno pod względem długości, głębokości rozcięcia, jak i objętości zerodowanego materiału. Gęstość rozcięć jest ponad dwukrotnie mniejsza niż gęstość wąwozów lessowych (Rodzik 2006), która na Zachodnim Roztoczu osiąga 10-11 $\mathrm{km} \cdot \mathrm{km}^{-2}$ (Buraczyński 1990). Podobną wartość, sięgającą $10 \mathrm{~km} \cdot \mathrm{km}^{-2}$, odnotowano także na obszarze nie pokrytym lessem na zboczach doliny Bugu w rezerwacie „Szwajcaria Podlaska" (Rodzik i in. 2011). Parów w AnielinieLipce bardzo aktywnie rozwijał się pod koniec okresu wpływów rzymskich epoki żelaza, co dokumentuje wynik datowania ${ }^{14} \mathrm{C}$ wynoszący $1490 \pm 100$ lat BP (LOD 519) oraz w średniowieczu (570 \pm 80 lat BP - LOD 520 i $480 \pm 70$ lat BP - LOD 518 ). Jest on przykładem formy niemal zupełnie nieprzeobrażonej przez człowieka, zachowanej w stanie naturalnym dzięki prawie $100 \%$ lesistości jego zlewni. Jedynie około 80-90 m zboczy parowu $(2,18 \%)$, znajdujących się w małym i płytkim, pobocznym odgałęzieniu północnym (por. rys. 5A, sygnatura 4) występuje w obrębie pól uprawnych i podlega przekształcaniu przez denudację agrotechniczną.
Parów w Brzezinach (rys. 6) rozcina prawe zbocze górnego odcinka doliny Mrożycy na obszarze Wzniesień Łódzkich. Jest nieco mniejszy od formy z Anielina-Lipki - suma długości rozcięć wynosi około $1500 \mathrm{~m}$, ich gęstość sięga $4,03 \mathrm{~km} \cdot \mathrm{km}^{-2}$, a objętość materiału zerodowanego wynosi 80150 $\mathrm{m}^{3}$. Początku rozwoju parowu nie udało się wyznaczyć z powodu braku materiału organicznego nadającego się do analizy radiowęglowej i zalegającego w odpowiedniej pozycji stratygraficznej. Niemniej wiadomo, że forma ta intensywnie rozwijała się także w średniowieczu, co dokumentują datowania ${ }^{14} \mathrm{C}$ wynoszące $460 \pm 80$ lat BP (LOD 465) i 390 \pm 90 lat BP (LOD 464) i w okresie nowożytnym (data ${ }^{14} \mathrm{C}$ około 270 lat BP - inf. ustna od W. Dylika). Parów w Brzezinach cechuje się znacznie dalej posuniętą ingerencją człowieka w jego rzeźbę. Zapisała się ona przekształceniem $517 \mathrm{~m}(34,5 \%)$ naturalnych zboczy parowu o prostym kształcie (rys. 6, sygnatura 3) w zbocza ,antropogeniczne” o ksztaltach wypukło-wklęsłych i wypukłych (rys. 6, sygnatura 4). Różnice kształtu stoków i przekrojów poprzecznych dla naturalnych (linie ciągłe) i przekształconych przez rolnictwo (linie przerywane) części parowu brzezińskiego dobrze obrazuje rys. 7. Co charakterystyczne, górne, płytsze części ramienia SE parowu uległy swoistej segmentacji i występuje tam naprzemienny układ części naturalnych (zadarnionych, a często także zalesionych) i zmienionych pod wpływem rolnictwa (fot. 4), z funkcjonującymi polami ornymi. Prawdopodobną przyczyną wyżej omówionych przeobrażeń rzeźby parowu brzezińskiego była silna presja rolnicza na zlewnię parowu (fot. 5) i chęć choćby częściowego odzyskania gruntów utraconych wskutek erozji wąwozowej.

Podobnie jak wyżej omówione parowy także parów w Dąbrówce Dużej jest wcięty w rozgałęziony system peryglacjalnych niecek i dolin denudacyjnych (rys. 8, sygnatury 1 i 2). Występuje w lewostronnej części zlewni wspomnianej wyżej rzeki Mrożycy, w strefie północnej krawędzi Wzniesień Łódzkich. Sumaryczna długość jego ramion i pobocznych odnóg wynosi $1070 \mathrm{~m}$, gęstość rozcięć sięga $1,25 \mathrm{~km} \cdot \mathrm{km}^{-2}$, a objętość formy wynosi około $49100 \mathrm{~m}^{3}$. Geomorfologiczne badania Wieczorkowskiej $(1986,1997)$ wskazują, że zlewnia parowu była penetrowana przez człowieka już w neolicie i epoce brązu, co potwierdzają datowania ${ }^{14} \mathrm{C}$ wynoszace $4650 \pm 160$ lat BP i $3500 \pm 160$ lat BP. Przytoczone datowania dokumentują powstawanie okryw stokowych, nie jest jednak pewne, czy można ich wyniki odnosić do powstania omawianego parowu. 

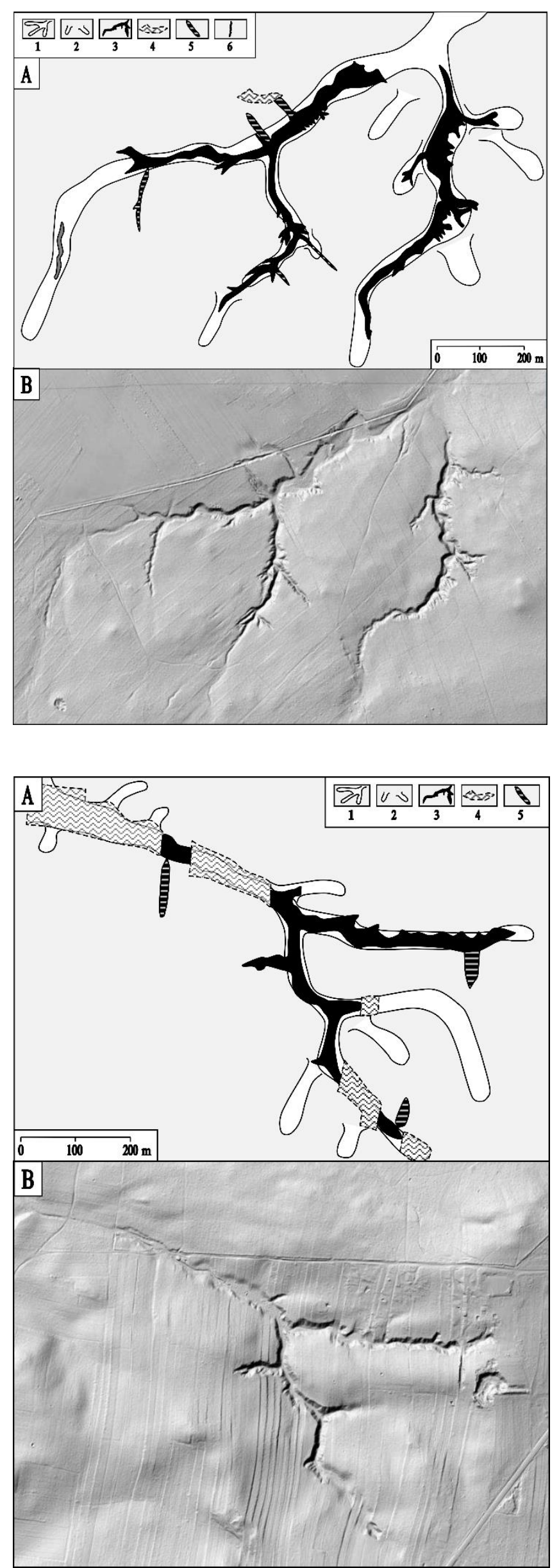

Rys. 5. Przeobrażenia parowów w AnielinieLipce pod wpływem uprawy ziemi

A - uproszczony szkic geomorfologiczny: $1-$ dna dolin denudacyjnych, 2 - dna niecek denudacyjnych, 3 - naturalne zbocza parowu, 4 - zbocza parowu zmienione przez denudację agrotechniczną, 5 - rozcięcia drogowe (tzw. holwegi), 6 - bruzda erozyjna; $\mathrm{B}-$ cieniowany relief parowu

Soil-cultivation-induced transformation of gullies in Anielin-Lipka

A - simplified geomorphological sketch: 1 - bottoms of denudational valleys, 2 - bottoms of denudational dells, 3 - natural slopes of gullies, 4 - gully slopes changed by tillage erosion, 5 - holwegs, 6 - erosional furrow; B - shaded relief of the gully

Rys. 6. Przeobrażenia parowu w Brzezinach pod wpływem uprawy ziemi

A - uproszczony szkic geomorfologiczny: $1-$ dna dolin denudacyjnych, 2 - dna niecek denudacyjnych, 3 - naturalne zbocza parowu, 4 - zbocza parowu zmienione przez denudację agrotechniczną, 5 - rozcięcia drogowe (tzw. holwegi); B - cieniowany relief parowów

Soil-cultivation-induced transformation of a gully in Brzeziny

A - simplified geomorphological sketch: 1 - bottoms of denudational valleys, 2 - bottoms of denudational dells, 3 - natural slopes of gullies, 4 - gully slopes changed by tillage erosion, 5 - holwegs, B shaded relief of the gully 


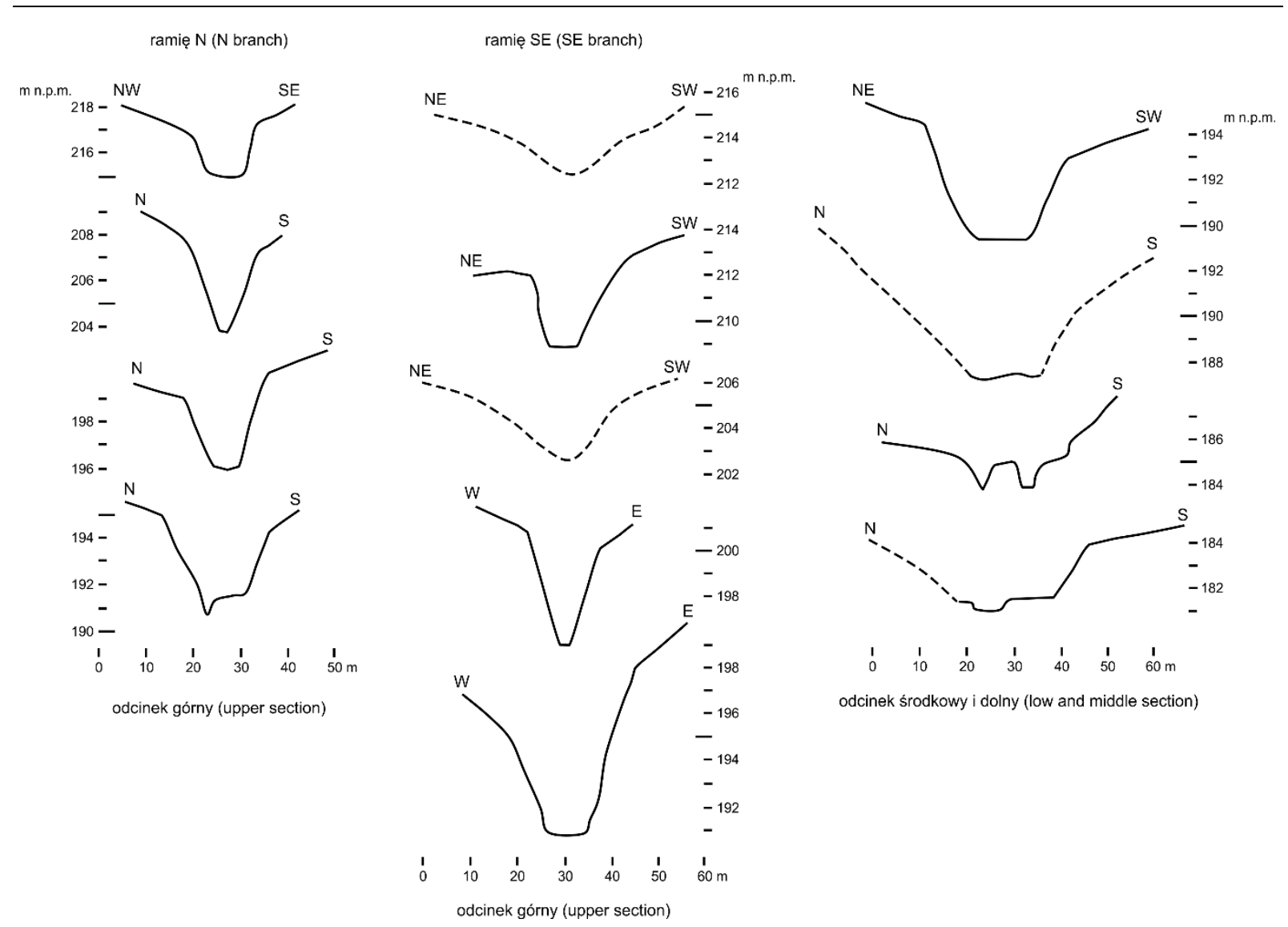

Rys. 7. Profile poprzeczne parowu w Brzezinach

linie ciągłe - naturalne zbocza parowu; linie przerywane - zbocza parowu zmienione przez denudację agrotechniczną

Transverse profiles of gully in Brzeziny

solid lines - natural slopes of gully; dotted lines - slopes of gully changed by tillage erosion

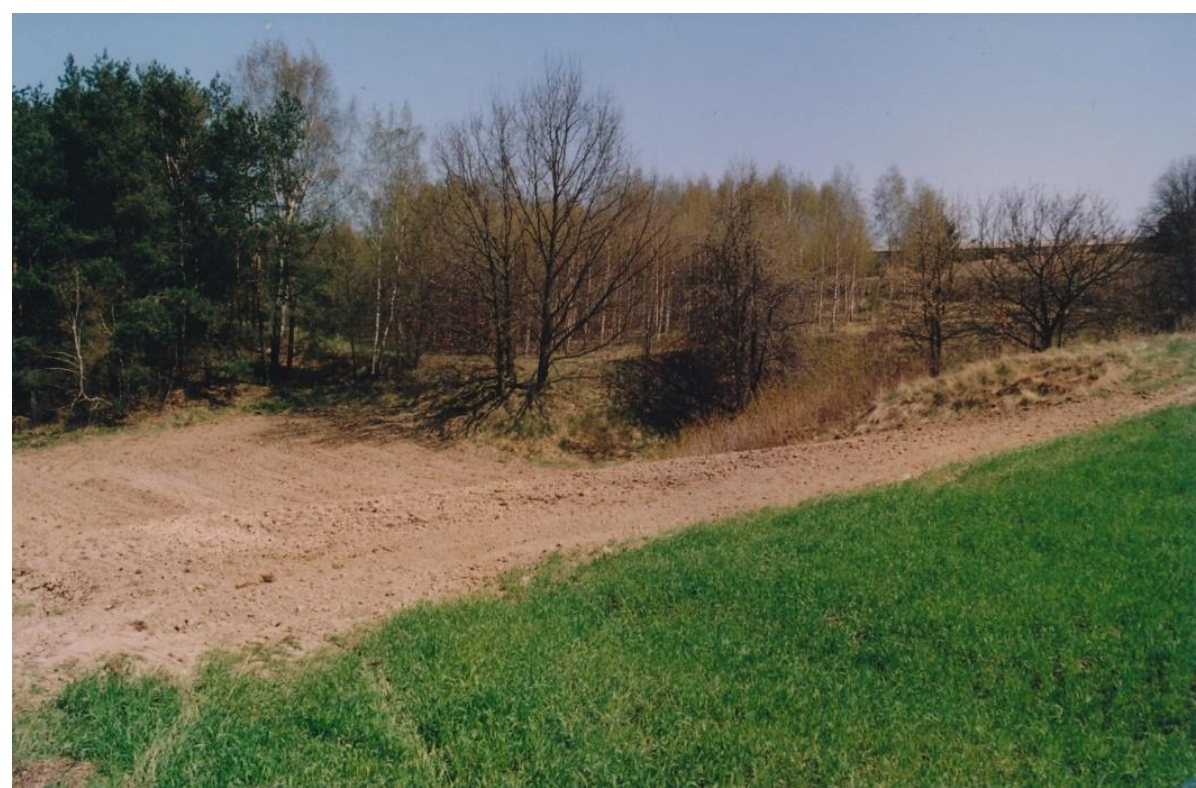

fot. J. Twardy, 1999

Fot. 4. Górna część ramienia SE parowu w Brzezinach

w głębi kadru naturalny, zalesiony segment parowu, „odcięty” przez uprawę ziemi i procesy denudacji agrotechnicznej

Upper part of the SE branch of a gully in Brzeziny

well inside the frame, a natural forested segment of the gully "cut off" by land cultivation and tillage erosion 


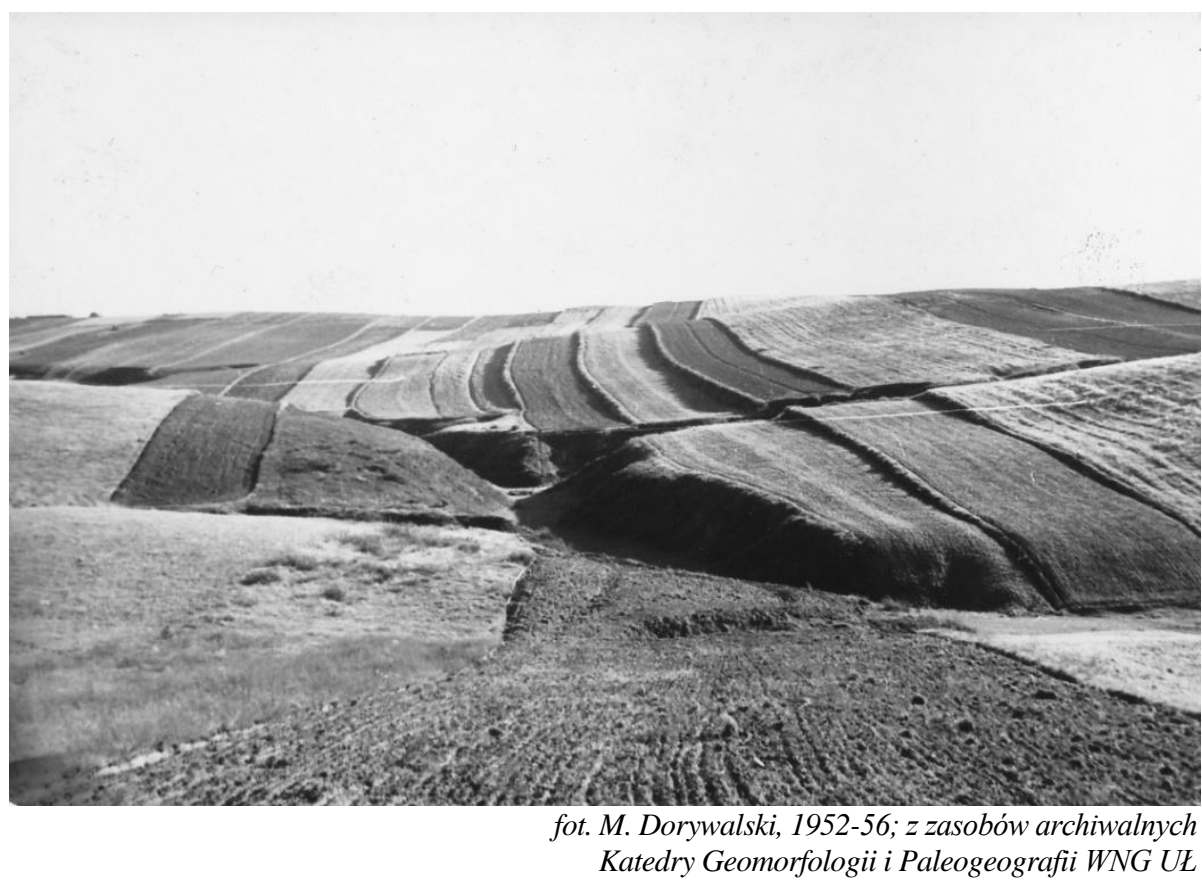

Fot. 5. Parów w Brzezinach na niepublikowanej fotografii prof. M. Dorywalskiego z lat 50 XX w.; uwagę zwraca kompletnie bezleśny krajobraz „stepu kulturowego”

Gully in Brzeziny on an unpublished photograph by Prof. M. Dorywalski from the 1950s; attention is drawn to the completely forestless landscape of the "cultural steppe"

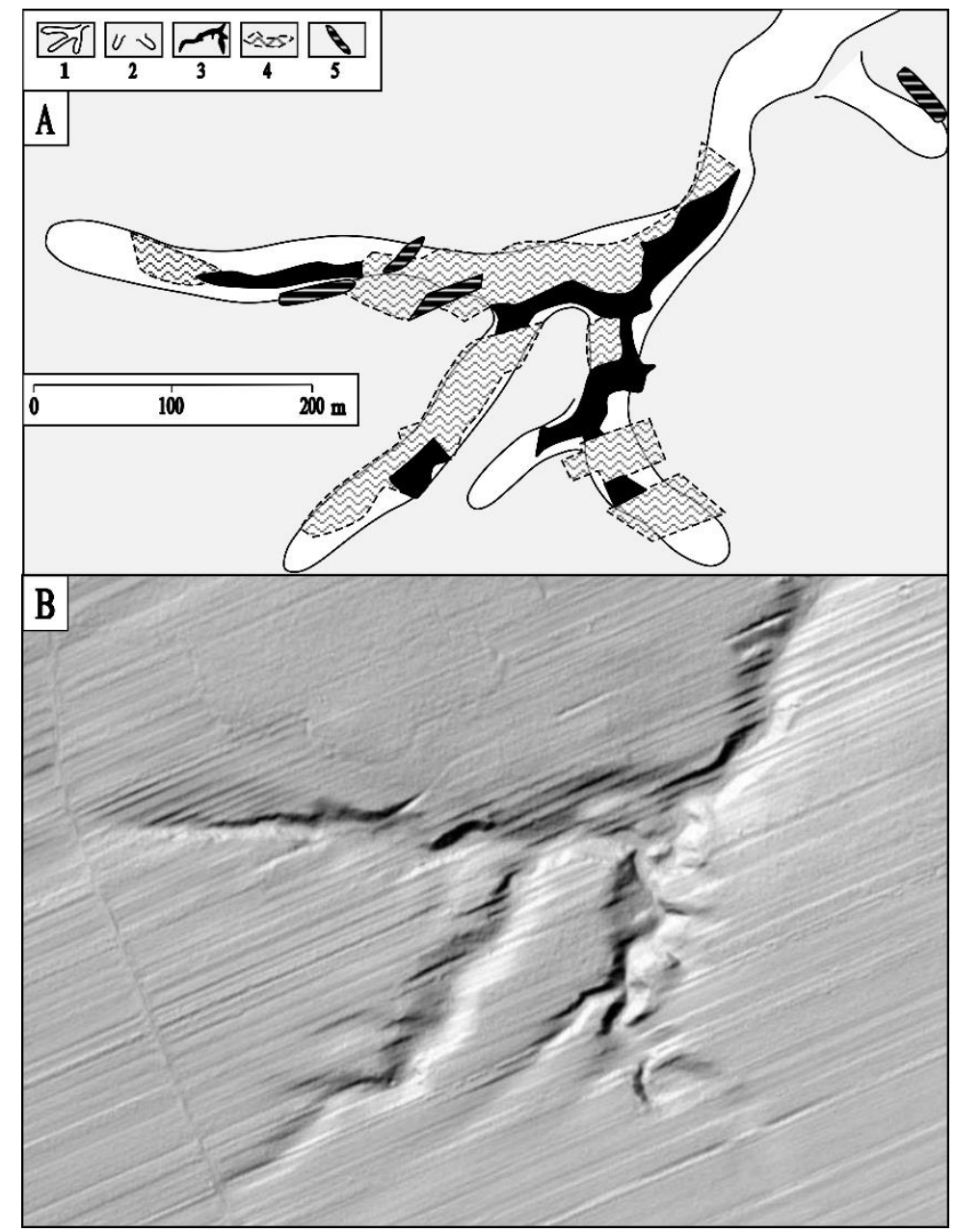

Rys. 8. Przeobrażenia parowu w Dąbrówce Dużej pod wpływem uprawy ziemi

A - uproszczony szkic geomorfologiczny: 1 - dna dolin denudacyjnych, 2 - dna niecek denudacyjnych, 3 - naturalne zbocza parowu, 4 - zbocza parowu zmienione przez denudację agrotechniczną, 5 - rozcięcia drogowe (tzw. holwegi); B - cieniowany relief parowu

Soil-cultivation-induced transformation of a gully in Dąbrówka Duża

A - simplified geomorphological sketch: 1 - bottoms of denudational valleys, $2-$ bottoms of denudational dells, 3 - natural slopes of gullies, 4 - gully slopes changed by tillage erosion, 5 - holwegs; $\mathrm{B}$ - shaded relief of the gully 
Forma z Dąbrówki Dużej jest najbardziej zmieniona przez uprawę ziemi, albowiem łączna długość stoków parowu, przez które przebiegają pola uprawne (rys. 8, sygnatura 4) wynosi $550 \mathrm{~m}$, co odpowiada $51,4 \%$. W każdym z trzech ramion parowu nastąpiła segmentacja przez wąskie niwy pól uprawnych (fot. 6), co jest widoczne na cieniowanym modelu rzeźby parowu (rys. 8B). Stoki parowu w miejscach gdzie przeprowadzono przez nie pola orne uległy spłaszczeniu, ich górne (a często także dolne) załamania zostały zniwelowane. Profil parowu nabrał charakteru nieckowatego (fot. 7) i zaczął ponownie odwzorowywać profil poprzeczny uprzednich form rzeźby - łagodnie zarysowanych peryglacjalnych niecek i dolin denudacyjnych. W wielu przypadkach na granicach pól uprawnych oraz odcinków naturalnych i zmienionych antropogenicznie doszło do wykształcenia się wysokich miedz (skarp uprawowych), których wysokości niejednokrotnie zbliżają się do $2 \mathrm{~m}$. Powoduje to, że mikrorelief parowu w Dąbrówce Dużej jest wyjątkowo żywy, miejscami wręcz „dziki”. Można powiedzieć, że parów w Dąbrówce Dużej wskutek nałożenia się na rzeźbę erozyjną szeregu form antropogenicznych (wysokie miedze, terasy rolne, antropogeniczne skarpy (progi) degradacyjne, antropogeniczne skarpy (progi) akumulacyjne itp. - por. Sinkiewicz 1998) nabrał cech tzw. badlands, niemniej trzeba podkreślić, że $\mathrm{w}$ jego zlewni trwa intensywna produkcja rolna.

Małe, młode rozcięcie erozyjne w Budach Grabskich występuje w dolinie rzeki Rawki na obszarze Równiny Łowicko-Błońskiej (Forysiak, Twardy 2012). Rozcina ono wysoką na $10 \mathrm{~m}$ krawędź równiny wodnolodowcowej, podciętej tu przez wielkopromienne paleomeandry Rawki. Rozcięcie ma kilkadziesiąt metrów długości i kilka metrów głębokości, cechuje się wciosowym, V-kształtnym profilem, jest prostolinijne i pozbawione ramion bocznych. Morfologia i pozycja rozcięcia wskazują, że jego powstanie może być związane z wcześniejszym funkcjonowaniem drogi leśnej, która mogła służyć do wywozu drewna $\mathrm{z}$ lasów porastających dolinę Rawki. Na możliwość warunkowania wąwozów i parowów transportem kołowym, który odbywał się wzdłuż nieutwardzonych dróg leśnych i polnych, uwagę zwracali między innymi Nowocień (1996) oraz Rodzik i Gardziel (2004). Rozcięcie jest skierowane ku brzeżnym, podstokowym partiom niskiej terasy Rawki, zajętej w podcięciach paleomeandrów przez torfowisko „Kopanicha". Strefa akumulacyjna rozcięcia jest ukształtowana w postaci dość regularnego stożka proluwialnego o promieniu około $25 \mathrm{~m}$ i miąższości około $1,5 \mathrm{~m}$, złożonego na torfach z makroszczą- tkami drzew w stropie. Drewno to wydatowano metodą ${ }^{14} \mathrm{C}$ na $385 \pm 50$ lat BP (MKL-768). U nasady stożka torfy były przykryte $25 \mathrm{~cm}$ gleby mułowotorfowej, której strop wykazał wiek radiowęglowy $80 \pm 35$ lat BP (MKL-767). Mineralne osady, złożone na stożku powyżej wspomnianej gleby mułowo-torfowej, były piaskami z domieszką zarówno żwirów, jak i mułów. Ich genezę można wiązać $\mathrm{z}$ formowaniem się rozcięcia krawędzi równiny wodnolodowcowej. Sytuacja młodego rozcięcia erozyjnego, które z jednej strony jest podobne do małych parowów zboczowych (Sobolew 1948; Muchowski 1977), a także do tzw. rozcięć drogowych (holwegów) wskazuje na dość ścisłe powiązanie jego morfogenezy $\mathrm{z}$ działalnością człowieka w ostatnim 100-leciu.

Podsumowując, trzeba podkreślić, że do zachodzących w minionym 100-leciu przeobrażeń form stokowych (parowów) w znacznym stopniu przyczynił się człowiek. Rekultywacja terenów zniszczonych przez erozję wąwozową powiodła się najlepiej $(51,4 \%)$ w przypadku najmniejszego i najpłytszego $\mathrm{z}$ analizowanych $\mathrm{w}$ niniejszej pracy parowu w Dąbrówce Dużej. Większy i głębszy parów w Brzezinach stanowił już poważniejsze wyzwanie - pola uprawne przeobrażające rzeźbę udało się wprowadzić jedynie w jego płytszych częściach, zarówno w odcinku dolnym, jak i gdzieniegdzie w odcinku górnym (34,5\%). W stosunku do największego, najgłębszego i najbardziej rozgałęzionego systemu parowów w Anielinie-Lipce, rekultywację pociągającą za sobą transformację rzeźby udało się zastosować jedynie w minimalnym procencie $(2,18 \%)$.

\section{Podsumowanie}

Ostatnie stulecie nie zapisało się w województwie łódzkim drastycznymi przemianami rzeźby, sterowanymi niektórymi procesami naturalnymi, takimi jak procesy stokowe i eoliczne. Analizę transformacji ukształtowania terenu utrudniała krótka, zaledwie 100-letnia cezura czasowa, przyjęta w związku z jubileuszem powstania województwa łódzkiego w roku 1919, a także szczupłość materiałów dotyczących współczesnej działalności procesów geomorfologicznych.

Zmiany rzeźby zboczy i stoków - najpowszechniej występujących elementów różnorodnych form geomorfologicznych - były najlepiej dostrzegalne w przypadku stosunkowo młodych, wyrazistych form rzeźby, takich jak parowy i podobne do nich młode rozcięcia erozyjne. Przeobrażenia parowów pod wpływem procesów naturalnych i antro- 


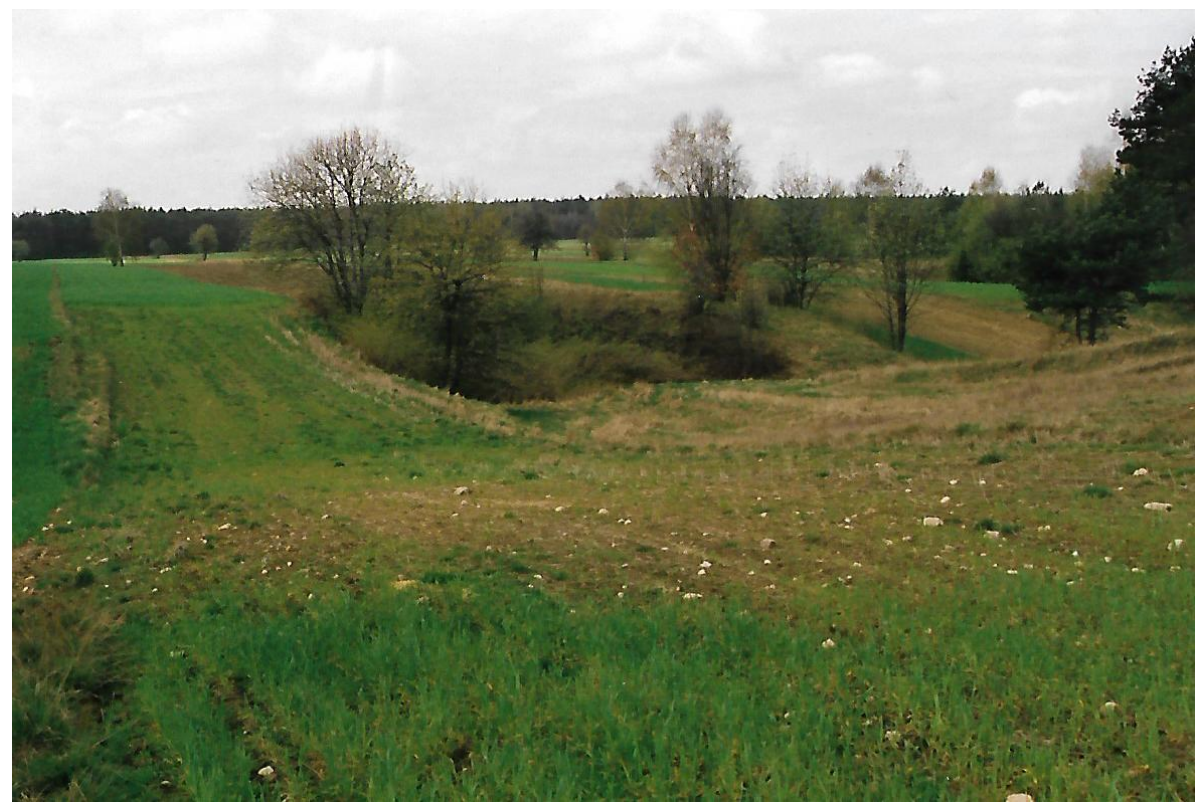

fot. J. Twardy, 1998

Fot. 6. Parów w Dąbrówce Dużej

w centrum kadru widoczny naturalny segment SE ramienia parowu, z obu stron wyodrębniony przez pola uprawne Gully in Dąbrówka Duża

in the centre of the frame, a natural segment of the SE branch of a gully separated on both sides by arable fields

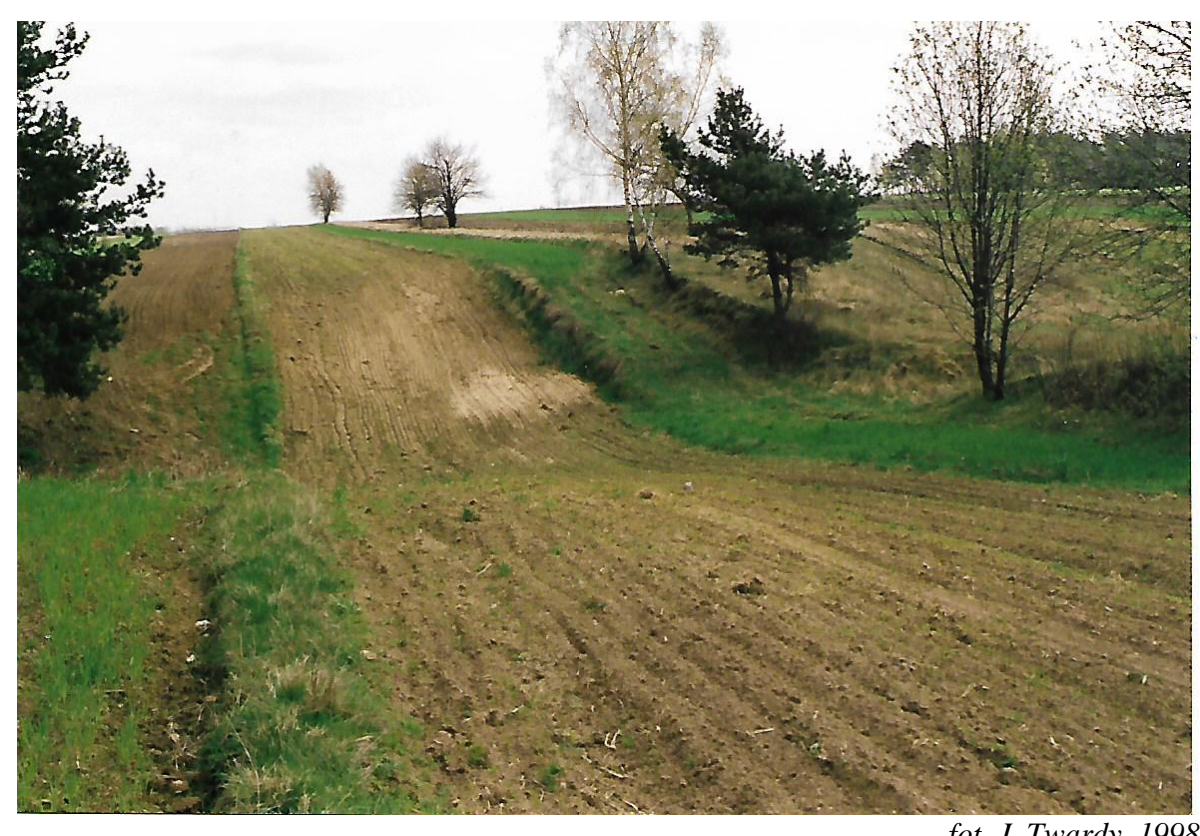

Fot. 7. Parów w Dąbrówce Dużej

pola uprawne w układzie wzdłużstokowym przecinające SE ramię parowu

Gully in Dąbrówka Duża

cultivated fields along the slopes cutting the SE branch of a gully 
pogenicznych, to znaczy denudacji agrotechnicznej, zapisały się wyraźnymi i dynamicznymi zmianami w ich profilach poprzecznych. Skala tych zmian była powiązana z rozmiarami parowów. Zaznaczyła się tu prawidłowość polegająca na najsilniejszej transformacji form nieco płytszych i mniej rozgałęzionych, których rekultywacja w kierunku rolnym nie przekraczała technicznych możliwości sprzężajnej i mechanicznej uprawy ziemi. Podkreślić trzeba, że wspomnianej transformacji podlegały zarówno formy rzeźby uprzedniej (neoholoceńskie parowy), a także nowe, małe formy rzeźby urozmaicające lokalne zbocza i stoki powstałe w ostatnim stuleciu.

Kierunki zmian rzeźby eolicznej były zasadniczo podobne do ewolucji rzeźby stoków. W ostatnim stuleciu zapisała się zarówno transformacja uprzednich form eolicznych (pokryw eolicznych i wydm późnovistuliańskich), ale lokalnie została także zainicjowana akumulacja eoliczna, prowadząca do uformowania się niewielkich kopczyków eolicznych. Rola człowieka w inicjowaniu przemian rzeźby eolicznej była niebagatelna; nieunikniona jest tu konstatacja, że uruchomienie zmian rzeźby wydm późnovistuliańskich w minionym stuleciu było konsekwencją błędów w zagospodarowaniu terenu. Uprawa zbyt wrażliwych na działalność wiatru przesuszonych gleb rozwiniętych z piasków i pyłów pochodzenia eolicznego i rzecznego skutkowała na tyle silnym rozwojem procesów eolicznych, że dochodziło do tworzenia się małych form akumulowanych przez wiatr i w konsekwencji wyłączania gruntów z uprawy.

Przedstawione $\mathrm{w}$ niniejszej pracy zmiany ukształtowania województwa łódzkiego mają jedynie lokalny charakter i można je określić jako retusz rzeźby terenu. Następowały one samorzutnie, lecz zawsze $\mathrm{w}$ powiązaniu $\mathrm{z}$ aktywnością człowieka, którego działalność osadnicza i gospodarcza w XX i XXI wieku urosła do rangi czynnika geomorfologicznego.

\section{Literatura}

Bogacki M., Starkel L. 1999. Typologia i regionalizacja współczesnych procesów rzeźbotwórczych. W: L. Starkel (red.) Geografia Polski. Środowisko przyrodnicze. Wyd. Nauk. PWN, Warszawa: 442-427.

Brown R.B., Cutshall N.H., Kling G.F. 1981. Agricultural erosion indicated by Ceasium-137 activity in soils. Soil Science Society of American Journal 45: 1184-1190.
Buraczyński J. 1990. Rozwój wąwozów na Roztoczu Gorajskim w ostatnim tysiącleciu. Annales UMCS 44/45, B: 95-104.

Dylik J. 1951. Utwory podobne do lessu w środkowej Polsce. Sprawozdania z Czynności i Posiedzeń VI/1(10), ŁTN, Łódź.

Dylik J. 1952. Głazy rzeźbione przez wiatr i utwory podobne do lessu w środkowej Polsce. Biuletyn Państwowego Instytutu Geologicznego 66: 231-332.

Dylikowa A. 1952. O metodzie badań strukturalnych w geomorfologii glacjalnej. Acta Geographica Universitatis Lodziensis 3: 1-74.

Dylikowa A. 1958. Próba wyróżnienia faz rozwoju wydm w okolicach Łodzi. Acta Geographica Universitatis Lodziensis 8: 233-268.

Dylikowa A. 1967. Wydmy środkowej Polski i ich znaczenie dla stratygrafii schyłkowego plejstocenu. W: R. Galon, J. Dylik (red.) Czwartorzęd Polski. Wyd. PWN, Warszawa: 353-371.

Forysiak J., Twardy J. 2012. Development of humaninduced geomorphological processes in the vicinity of peatlands of Central Poland. W: J. Forysiak, L. Kucharski, M. Ziułkiewicz (red.) Peatland in semi-natural landscape - their transformation and possibility of protection. Bogucki Wyd. Nauk., Poznań: 85-99.

Galon R. 1958. Z problematyki wydm śródlądowych w Polsce. W: R. Galon (red.) Wydmy śródladowe Polski, 1. PWN, Warszawa: 13-31.

Gawlik H. 1969. Wydmy w Kotlinie Szczercowskiej. Prace Geograficzne IG PAN, 75: 249-287.

Govers G., Quine T.A., Desmet P., Poesen J., Bunte K. 1994. The role of tillage in soil redistribution on hillslopes. European Journal of Soil Science 45: 469-478.

Goździk J. 1986. Czas w geomorfologii. Przegląd zagadnień metodologicznych. Czasopismo Geograficzne LVII/2: 183-201.

Hildebrandt-Radke I., Stróżyk M., Czebreszuk J., Jaeger M., Pospieszny Ł., Cwaliński M., Niebieszczański J., Rotnicka J. 2018. Wykorzystanie metody litologicznej do weryfikacji rezultatów nieinwazyjnych badań kurhanów z epoki brązu na pograniczu śląsko-wielkopolskim (Las Krotoszyn, Wielkopolska). Acta Geographica Lodziensia 107: 73-92.

Janicki G. 2016. System stoku zmywowego i jego modelowanie statystyczne - na przykładzie Wyżyn Lubelsko-Wołyńskich. Wyd. UMCS, Lublin.

Józefaciuk A., Józefaciuk C. 1979. Próba oceny zagrożenia gruntów w Polsce erozją wietrzną. $P a-$ miętnik Puławski 71: 151-176.

Józefaciuk A., Józefaciuk C. 1992. Gęstość sieci wąwozowej w fizjograficznych krainach Polski. Pamiętnik Puławski 101: 51-66.

Józefaciuk A., Józefaciuk C. 1995. Erozja agroekosystemów. Państwowa Inspekcja Ochrony Środo- 
wiska, Biblioteka Monitoringu Środowiska, Warszawa.

Józefaciuk A., Józefaciuk C. 1996. Mechanizm i wskazówki metodyczne badania procesów erozji gleb. Państwowa Inspekcja Ochrony Środowiska, Biblioteka Monitoringu Środowiska, Warszawa.

Kobendza J., Kobendza R. 1958. Rozwiewanie wydm Puszczy Kampinoskiej. W: R. Galon (red.) Wydmy śródlądowe Polski, 1. PWN, Warszawa: 95-170.

Kossman O. 1930. O wydmie aleksandrowskiej. Czasopismo przyrodnicze, IV. Wydawnictwo Towarzystwa Przyrodniczego im. St. Staszica w Łodzi, Łódź: 257-264.

Krzemiński T. 1965. Przełom doliny Warty przez Wyżynę Wieluńską. Acta Geographica Lodziensia 21: 1-95.

Maksymiuk Z. 1992. Zależność między gęstością sieci rzecznej a przepuszczalnością podłoża w środkowej Polsce. Acta Geographica Lodziensia, Folia Geographica 16: 7-17.

Maruszczak H. 1980. Stratigraphy and chronology of the Vistulian loesses in Poland. Quaternary Studies in Poland 2: 57-76.

Muchowski J. 1977. Młode wcięcia erozyjne południowej strefy krawędziowej Wyżyny Lubelskiej, ich geneza, wiek i dynamika rozwoju. Biuletyn Geologiczny 22: 117-154.

Musierowicz A. (red.) 1961a. Mapa gleb Polski w skali 1:300 000, arkusz C3 (Płock). Wydanie A, Instytut Uprawy, Nawożenia i Gleboznawstwa.

Musierowicz A. (red.) 1961b. Mapa gleb Polski w skali 1:300 000, arkusz D3 (Łódź). Wydanie A, Instytut Uprawy, Nawożenia i Gleboznawstwa.

Nowocień E. 1996. Dynamika rozwoju wąwozów drogowych na obszarach lessowych. Pamiętnik Puławski 107: 101-111.

Pełka-Gościniak J. 2000. Development of aeolian relief in areas transformed by human impact (a case study of Bukowno neighbourhood eastern part of Silesian Upland). W: R. Dulias, J. Pełka-Gościniak (red.) Aeolian processes in different landscape zones. Uniwersytet Śląski, SGP, Sosnowiec: 129-142.

Rodzik J. 2006. Wąwozy - naturalne czy kulturowe elementy krajobrazu? Problemy Ekologii Krajobrazu 18: 377-382.

Rodzik J., Gardziel Z. 2004. Układy krajobrazowe wąwozów kazimierskich. W: M. Kucharczyk (red.) Współczesne problemy ochrony krajobrazu. Zarząd Zespołu Lubelskich Parków Krajobrazowych, Lublin: 85-92.

Rodzik J., Terpiłowski S., Godlewska A. 2011. Influence of field and road pattern change on gully development in the Bug River valley side ( $\mathrm{E}$ Poland). Landform Analysis 17: 145-149.

Rzepecki S., Twardy J., Forysiak J. 2015. LiDAR, barrows and aeolian hillocks. Between theory and practice. Sprawozdania Archeologiczne 67: 101-112.

Sinkiewicz M. 1989. Zmiany rzeźby terenu Pojezierza Kujawskiego pod wpływem procesów stokowych. Studia Societatis Scientiarum Torunensis $\mathrm{C}, 9,6$ : 1-104.

Sinkiewicz M. 1991. Znaczenie denudacji antropogenicznej w przeobrażaniu niektórych elementów środowiska geograficznego w okolicy Turka. W: W. Stankowski (red.) Przemiany środowiska geograficznego obszaru Konin-Turek. Inst. Bad. Czwart. UAM, Poznań: 232-239.

Sinkiewicz M. 1995. Przeobrażenia rzeźby terenu i gleb w okolicy Biskupina wskutek denudacji antropogenicznej. W: W. Niewiarowski (red.) Zarys zmian środowiska geograficznego okolic Biskupina pod wplywem czynników naturalnych $i$ antropogenicznych $w$ późnym glacjale i holocenie. Ofic. Wyd. „Turpres”, Torun: 247297.

Sinkiewicz M. 1998. Rozwój denudacji antropogenicznej w środkowej części Polski północnej. Wyd. UMK, Torun.

Sobolew S.S. 1948. Razwitije erozjonnych procesow na tieritorji jewropiejskoj czasti SSSR i borba s nimi. Izd. Akad. Nauk SSSR. Moskwa-Leningrad.

Szczypek T. 1994a. Inicjalne kopczyki piaszczyste typu "nebkha". W: B. Nowaczyk, T. Szczypek (red.) Vistuliańsko-holoceńskie zjawiska i procesy eoliczne (wybrane zagadnienia). Wyd. SGP, Poznań: 89-98.

Szczypek T. 1994b. Pasowość rzeźby deflacyjno-akumulacyjnej (na przykładzie piaskowni w Bukownie na Wyżynie Śląskiej. W: B. Nowaczyk i T. Szczypek (red.) Vistuliańsko-holoceńskie zjawiska i procesy eoliczne (wybrane zagadnienia). Wyd. SGP, Poznań: 77-88.

Szczypek T., Wach J. 1991. Rozwój współczesnej wydmy w warunkach silnej antropopresji. U Śl., Katowice.

Szczypek T., Wach J. 1993. Antropogenicznie uwarunkowane procesy i formy eoliczne na Wyżynie Śląskiej. SGP, Poznań.

Szczypek T., Wach J. 1998. Rozwój pagórków antropogenicznych pod wpływem czynnika eolicznego. W: T. Szczypek, J. Wach (red.) Wspótczesne procesy eoliczne. SGP, Sosnowiec: 5-20.

Szpikowski J. 2010. Antropogeniczne przekształcenia rzeźby zlewni Perznicy w neoholocenie (Pojezierze Drawskie, dorzecze Parsęty). Wyd. Nauk UAM, Poznań.

Twardy J. 1995. Dynamika denudacji holoceńskiej w strefie krawędziowej Wyżyny Łódzkiej. Acta Geographica Lodziensia 69: 1-213.

Twardy J. 2005. Gully erosion in middle Poland. W: J. Rejman, W. Zgłobicki (eds) Human impact on sensitive geosystems. UMCS, Lublin: 129-142. 
Twardy J. 2008. Transformacja rzeźby centralnej części Polski Środkowej w warunkach antropopresji. Wyd. UŁ, Łódź.

Twardy J. 2012. Przykłady długiego transportu stokowego z centralnej Polski w świetle obserwacji terenowych i analiz zdjęć lotniczych. Prace i Studia Geograficzne 49: 185-210.

Twardy J. 2016. Antropogeniczna faza wydmotwórcza w środkowej Polsce. W: J. Święchowicz, A. Michno (red.) Wybrane zagadnienia geomorfologii eolicznej. Monografia dedykowana $d r$ hab. Bogdanie Izmaiłow w 44 rocznice pracy naukowej. IGiGP UJ w Krakowie, Kraków: 157-184.

Wieczorkowska J. 1986. Efekty spłukiwania vistuliańskiego i holoceńskiego na krawędzi Wyżyny Łódzkiej. II Zjazd Geografów Polskich, Łódź, 11-13.09.1986 r. Wyd. UŁ, Łódź: 27-28.

Wieczorkowska J. 1997. Przykłady parowów na krawędzi Wyżyny Łódzkiej. Acta Geographica Lodziensia, Folia Geographica Physica 1: 258261.

Wojtanowicz J. 1999. Procesy eoliczne. W: L. Starkel (red.) Geografia Polski. Środowisko przyrodnicze. PWN, Warszawa: 410-413.

Wojtanowicz J. 2009. Współczesne procesy eoliczne w Europie. Prace i Studia Geograficzne 41: 235-244.

Zaslavskij M N. 1978. Erozia počv. Izdatielstwo „Mysl”, Moskwa.

Zawadzki S. (red.) 2002. Podstawy gleboznawstwa. PWRiL, Warszawa.

Zgłobicki W. 2002. Dynamika współczesnych procesów denudacyjnych w północno-zachodniej części Wyżyny Lubelskiej. UMCS, Lublin.

Ziemnicki S., Józefaciuk C. 1965. Erozja i jej zwalczanie. PWRiL, Warszawa.

\section{Summary}

The paper deals with the relief changes in the Łódź Voivodeship over the past 100 years. Due to the specificity of research at the geomorphological centre in Łódź, the issue of contemporary morphological activity was somewhat neglected. This resulted in, for example, a lack of data on fluvial morphogenic activity in the last 100 years and a general scarcity of data on the activity of aeolian and slope processes. In view of the above, the analysis of relief changes was limited to the presentation of three cases of transformations of aeolian landforms and four cases of transformations of forms occurring on slopes, such as gullies and other young erosional cuts.
The voivodeship area's susceptibility to wind activity and sensitivity to the impact of slope processes were considered. It was found that the susceptibility of that area to aeolian processes is strongly spatially diversified and largely dependent upon soil cover. Those most exposed to wind activity were considered to be old late-glacial dunes and interfluve areas covered with overdried sandy and silty soils. Areas exposed to the activity of slope processes such as surface wash and gully erosion are concentrated in the most morphologically diversified parts of the Łódź Voivodeship, i.e. in the northern edge of the Lódź Hills, on the Rawa Plateau and in the southern, upland parts of the voivodeship.

The scale of transformations of the relief of the Łódź Voivodeship area by aeolian processes in the last century was considered to be small. The following two directions of aeolian relief transformation were distinguished, and illustrated by examples and discussed in greater detail: 1) the formation of new initial accumulation landforms, such as small dune hillocks, and 2) relatively slight transformation of the relief of old, large, late-glacial dunes. In both directions, the human influence on transformation of the aeolian relief was highlighted. The discussed transformation occurred as a result of human errors in land development - deforestation and over-intensive cultivation of sandy areas sensitive to wind activity.

The scale of the transformation of the slopes was generally also recognised to be small, although locally the relief changes in some of the presented gullies were easily discernible. As was the case with dunes, two directions of transformation of the slopes were noted: 1) the formation of new, small but permanent erosional forms, similar to initial gullies or holwegs, and 2) the transformation of the slope profiles of older forms - large Neoholocene gullies under the influence of land cultivation. In the case of one of the presented gullies, these changes covered $51.4 \%$ of its slopes and were recorded by the rapid transformation of natural slopes from straight into convex and convex-concave. This was connected with the transformation of the transverse gully profile from V-shaped erosional into a gentler troughshaped profile. As a result, the slope gradients and deeps tended to reduce with time. The close relationship between the discussed changes and anthropogenic processes, i.e. tillage erosion, was emphasised. 